\title{
Gender Inequity in Education in Algeria: When Inequalities are Reversed
}

\author{
Ouadah-Bedidi Zahia \\ Université Paris Diderot- Paris 7 \\ Unité de Recherche Migrations et Sociétés (URMIS) \\ Institut national d'études démographiques (INED), Paris \\ France
}

\begin{abstract}
In Algeria, education was long a privilege reserved for men. Since Algeria became independent, one of the priorities of the country has been to bring all children, regardless of sex, to school. Forty years after independence, almost all children aged 6-15 (both boys and girls) attend school, and access to upper secondary schools and universities has been opened to everyone. However, past age 16 (the limit for compulsory schooling), girls continue to study longer than boys, and have more success earning diplomas, a trend which reflects a surprising inversion of the gender imbalance in education. This phenomenon, which started in large cities and some pioneering wilayas, quickly spread to villages and diffused throughout the national territory. This is one of the major changes that has taken place in modern Algeria, the development of which must be analysed objectively, as it brings up many questions concerning its causes and effects.
\end{abstract}

Keywords: Algeria, education, gender inequalities

\section{Introduction}

In Algeria, enrollment and education have long been privileges enjoyed by men, who have historically had higher rates of enrollment at 5-14 years, higher literacy rates as adults, higher diplomas obtained, higher levels of education by age, and so on. Until the 1990s, the indicators in every census and demographic survey pointed to this trend. However, the policy to educate all children, regardless of sex, that has been implemented in the country since its independence has had results well beyond the expected effect. Not only did free and compulsory education for children up to 16 years old quickly prove to be enough to provide basic education for all children, but once they entered the school system, girls were found to be more likely to take full advantage of their education, and continue their studies into high school and university. Since the early 2000s, this phenomenon has become increasingly evident in the records of the Ministry of Education and the National Office of Statistics (ONS) (Ouadah-Bedidi, 2004; CNES, 2006 and 2007; ONS 2006, 2009, 2010 and 2011). This imbalance between men and women in terms of educational achievements is now clearly tipped in favor of women: in high school and university, the graduation rate for girls far exceeds that of boys.

This phenomenon is not specific to Algeria. Females catching up to males in secondary schools and at university had already been identified as a global trend by international agencies by the end of the 1980s (UNESCO, 1989; PNUD, 1991). In France, for example, the number of girls who earned their baccalauréat (high school diploma) had exceeded that of boys by the mid-1960s (Lévy, 1981), and the gap continued to widen in the years that followed (Baudelot and Establet, 1992; Caspard, 2007). Given Algeria's more entrenched social inequalities, one might have expected that the spread of schooling would lead to less gender inequality in education; it would have been difficult to imagine, however, these policies would lead to a complete reversal. Before examining the causes and outcomes of this phenomenon, it is necessary to begin by taking a closer look at the evolution of the gender ratio in each cycle of education: primary, secondary, and university. The aim of this article is to give as complete a picture as possible of this phenomenon. The first part will follow in detail the evolution observed at the national level, and the second part will focus on the diversity that is overshadowed by national averages, with particular emphasis on city-country contrasts and geographical disparities in educational achievement beyond the period of compulsory schooling. Finally, a third section will be devoted to the reasons that may explain Algerian girls' unexpected rise to dominance in the field of education. 


\section{When Gender Inequality in Education Reverses in Favor of Women}

Following Algeria's independence, one of the major objectives of the Algerian government was to at once eradicate illiteracy and guarantee basic education for all children. Half a century later, this goal has almost been fully realized. Since then, inequality between the sexes has almost disappeared with regard to basic education. What was not expected, however, was the reemergence of a gender imbalance at the secondary and higher education levels - this time in favor of girls.

\section{I.1 The disappearance of illiteracy and near-universal access to primary and secondary education}

Since Algeria's independence in 1962, the government policy that has been most beneficial to the improvement of the status of women has undoubtedly been the opening of universal access to education, which was made compulsory and free for children between the ages of 6 and $16^{\mathrm{i}}$. Reaching this objective was a real challenge given the demographic situation of the 1960s. Because of its extremely rapid growth, the Algerian population was very young (47\% under the age of 15 in 1966) and the number of enrollments rose rapidly until a decline in fertility eventually controlled the pace. The vast majority of the population, however, was illiterate: according to the 1966 census, $75 \%$ of people aged 10 and over could neither read nor write. This percentage was even more than $85 \%$ for women, compared to $62 \%$ for men (Table 1). Although initially, the struggle against illiteracy and the spread of "fundamental" education ${ }^{\text {ii }}$ benefited men more so than women (the gap having first widened between 1966 and $1977^{\mathrm{iii}}$ before starting to close in the late 1970s), exceptional progress has been made. According to estimates by the National Economic and Social Council (CNES), in 2011 the illiteracy rate was only $15 \%$ for men and $21 \%$ for women ${ }^{\text {iv }}$. In 2011 , illiteracy had declined by more than $75 \%$, while the difference between men and women had significantly decreased (Table 1). It should also be pointed out that although the illiteracy rate remains higher for women, it is largely because the proportion of very elderly illiterate women (too old to have benefited from this progress) is greater than that of men.

Table 1. Illiteracy Rate (\%) of the Population Aged 10 Years and Over in Algeria, 1966 to 2011

\begin{tabular}{|c|c|c|c|c|c|}
\hline & & Men & Women & Total & $\begin{array}{c}\text { Difference } \\
\text { (Women } \square \text { Men) }\end{array}$ \\
\hline $1966(1)$ & (a) & 62.3 & 85.4 & 74.6 & 23.1 \\
\hline $1969(2)$ & (b) & 51.4 & 80.6 & & 29.2 \\
\hline $1977(1)$ & (c) & 48.2 & 74.3 & 58.1 & 26.1 \\
\hline $1987(1)$ & (d) & 30.8 & 56.7 & 43.6 & 25.9 \\
\hline $1998(1)$ & (e) & 23.7 & 40.3 & 31.9 & 16.6 \\
\hline 2008 (1) & (f) & 15.1 & 28.9 & 22.1 & 13.8 \\
\hline $2008-2009$ (3) & (g) & 15.1 & 26.2 & 20.6 & 11.1 \\
\hline $2009-2010(3)$ & (h) & 14.8 & 23.8 & 19.2 & 9.0 \\
\hline $2010-2011(3)$ & (i) & 14.4 & 21.1 & 17.6 & 6.7 \\
\hline $\begin{array}{c}\text { Relative } \\
\text { Evolution (\%) }\end{array}$ & $\begin{array}{l}{[(\mathrm{i})-} \\
(\mathrm{a}) /(\mathrm{a}) \\
\quad]\end{array}$ & $-77 \%$ & $-75 \%$ & $-76 \%$ & -0.71 \\
\hline \multicolumn{6}{|c|}{$\begin{array}{l}\text { Sources: } \\
\text { suses (ONS, 2011). } \\
9 \text { (CNRES, 1974): only northern Algeria. } \\
\text { n of CNES; unpublished. }\end{array}$} \\
\hline
\end{tabular}


Over the same period of time, enrollment rates for children aged 6 to 14 also saw tremendous growth. Whereas at that age, fewer than one child in two went to school in 1966 (57\% of boys, 37\% of girls), almost $92 \%$ of children are now in school, with a very small residual gap remaining between boys and girls $(92.4 \%$ vs. $91.7 \%$ in 2008$)$ (Table 2).

Table 2. Enrollment rate (\%) by Sex and Age in Algeria, from 1966 to 2008

\begin{tabular}{|c|c|c|c|c|c|}
\hline Age & $1966(1)$ & $1969(2)$ & 1987(3) & $1998(4)$ & $2008(4)$ \\
\hline \multicolumn{6}{|l|}{ Males } \\
\hline 6 & 36 & 54.4 & 67.9 & 57.5 & 78.2 \\
\hline 7 & 57.2 & 69.5 & 89.7 & 87.9 & 93.6 \\
\hline 8 & 59.3 & 71.5 & 91.9 & 89.8 & 95 \\
\hline 9 & 66.4 & 74 & 92.2 & 90.3 & 95.2 \\
\hline 10 & 61.8 & 70.9 & 92.3 & 90.3 & 95.5 \\
\hline 11 & 67.2 & 72.1 & 91.2 & 89.8 & 95.2 \\
\hline 12 & 59.7 & 65.9 & 89.7 & 88.3 & 94.7 \\
\hline 13 & 63.6 & 65.5 & 85.1 & 85.5 & 93.5 \\
\hline 14 & 55.6 & 56.9 & 79.2 & 80.2 & 90.7 \\
\hline 15 & & & 70.8 & 71.2 & 85.2 \\
\hline $6-9$ & 52.2 & 66.3 & 85 & & 90.4 \\
\hline $6-14$ & 56.8 & & 86.4 & 85.3 & 92.4 \\
\hline $6-15$ & & & 85 & 83.1 & 91.6 \\
\hline $10-14$ & 60.7 & 66.3 & 87.6 & & 93.8 \\
\hline \multicolumn{6}{|c|}{ Females } \\
\hline 6 & 24.8 & 39.6 & 59.4 & 56.3 & 78.2 \\
\hline 7 & 41.1 & 49.6 & 77.8 & 85.8 & 93.4 \\
\hline 8 & 41.3 & 51.1 & 79.6 & 87.3 & 94.8 \\
\hline 9 & 47 & 50.9 & 78.6 & 87.3 & 94.9 \\
\hline 10 & 41.5 & 47 & 77.1 & 86.5 & 95.1 \\
\hline 11 & 44.6 & 46 & 72.5 & 85.4 & 94.7 \\
\hline 12 & 36.7 & 39.5 & 70 & 82.2 & 93.7 \\
\hline 13 & 36.2 & 35.7 & 63.5 & 77.6 & 91.7 \\
\hline 14 & 27.5 & 25.8 & 58.1 & 71.5 & 88.8 \\
\hline 15 & & & 52.1 & 63.6 & 82.8 \\
\hline $6-9$ & 36.7 & 47.2 & 73.6 & & 90.2 \\
\hline 6-14 & 36.9 & & 70.9 & 80.7 & 91.7 \\
\hline $6-15$ & & & 69.3 & 78.3 & 90.6 \\
\hline $10-14$ & 37.1 & 39 & 68.4 & & 92.6 \\
\hline \multicolumn{6}{|c|}{ Difference (Males - Females) } \\
\hline 6 & 11.2 & 14.8 & 8.5 & 1.2 & 0 \\
\hline 7 & 16.1 & 19.9 & 11.9 & 2.1 & 0.2 \\
\hline 8 & 18 & 20.4 & 12.3 & 2.5 & 0.2 \\
\hline 9 & 19.4 & 23.1 & 13.6 & 3 & 0.3 \\
\hline 10 & 20.3 & 23.9 & 15.2 & 3.8 & 0.4 \\
\hline 11 & 22.6 & 26.1 & 18.7 & 4.4 & 0.5 \\
\hline 12 & 23 & 26.4 & 19.7 & 6.1 & 1 \\
\hline 13 & 27.4 & 29.8 & 21.6 & 7.9 & 1.8 \\
\hline 14 & 28.1 & 31.1 & 21.1 & 8.7 & 1.9 \\
\hline 15 & & & 18.7 & 7.6 & 2.4 \\
\hline $6-9$ & 16.8 & 19.1 & 11.5 & & 0.1 \\
\hline $6-14$ & 19.9 & & 15.5 & 4.6 & 0.7 \\
\hline $6-15$ & & & 15.7 & 4.8 & 1 \\
\hline $10-14$ & 23.6 & 27.3 & 19.2 & 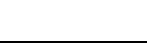 & 1.2 \\
\hline
\end{tabular}


It should be noted, however, that although education is mandatory for all children up to the age of 16, in 2008, not all children between the ages of 6 and 15 were in school. Beyond the fact that a small number of children cannot, for various reasons (health in particular) enroll in school, the 2008 census (the latest available data on the subject), also revealed that the overall enrollment rate decreases significantly after children pass the age of 10 (Table 2). At this age, the overall enrollment rate is around $95 \%$ (95.5\% for boys and $95.1 \%$ for girls) - by age 15, however, the number drops almost 10 points for boys (to $85.2 \%$ ) and more than 12 points for girls $(82.8 \%$ ). It can nevertheless be said that in this respect, the situation has greatly improved for girls; although there is still a gender gap when it comes to enrollment, dropout rates before the compulsory school-leaving age are, on the whole, marginal compared to what was observed in 1966 and even 1987 (Figure 1).

Rate (\%)

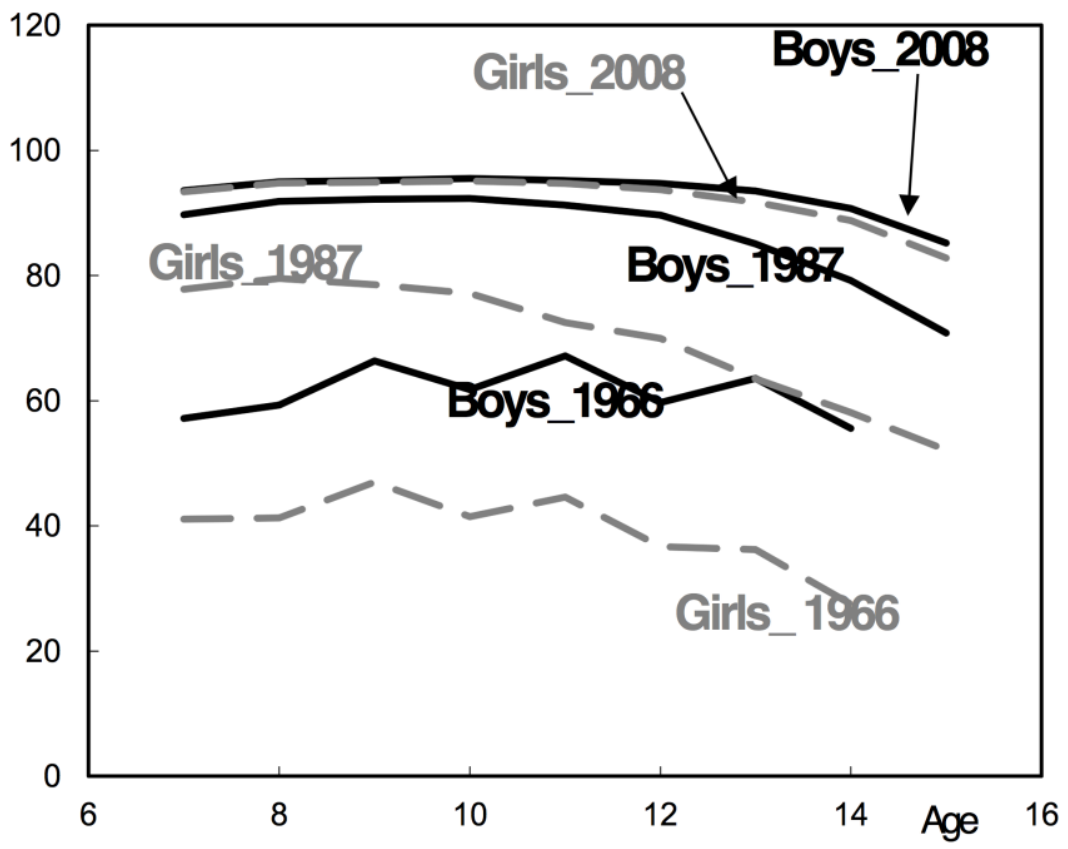

Figure 1. Enrollment Rates by Age According to the 1966, 1987 and 2008 Censuses Source; Data from Table 2

A compilation of the annual statistics of the Ministry of National Education, published by the ONS in 2012, has made it possible to more clearly visualize the overall increase in enrollment rates for children between the ages of 6 and 13 up to the 1986-87 school year, and then for children between the ages of 6 and 15 since the 1987-1988 school year, by sex (Figure 2A). Progress in enrollment rates was swift - and roughly parallel - for both sexes until the mid-1970s. After this point, rates quickly plateaued for boys, but continued to rise for girls, who nearly closed the gap in the three decades that followed.

The same compilation of statistics also gives the numbers of girls and boys enrolled in each cycle of basic education, regardless of age, thus making it possible to calculate the proportion of each sex in school during each cycle (Figure 2B). In the first and second cycles combined, the percentage of girls increased from 33\% in 1965-66 to $47 \%$ in 2008. In the 3rd cycle of basic education (on average), the phenomenon was even more marked, increasing from $27 \%$ to nearly $50 \%$ (Figure 2B). Compared with the dropout rate after 10 years (which is higher for girls than for boys), this gender equality in the 3rd cycle of basic education can only be explained by higher graduation rates among girls in primary school. As a result of this apparent rise in success, girls are held back less often than boys, and are often as numerous as their male classmates once they reach the third cycle of basic education. In fact, a recent UNICEF study (2014) shows that in the final year of the second cycle, for example, twice as many boys as girls are held back each year. The repetition rate, estimated at 30\% in 2003-2004, was higher among boys (Kocoglu, 2014). It seems, therefore, that even in an age group where schooling is compulsory for all, more girls than boys are actually able to complete the three cycles of basic education. 

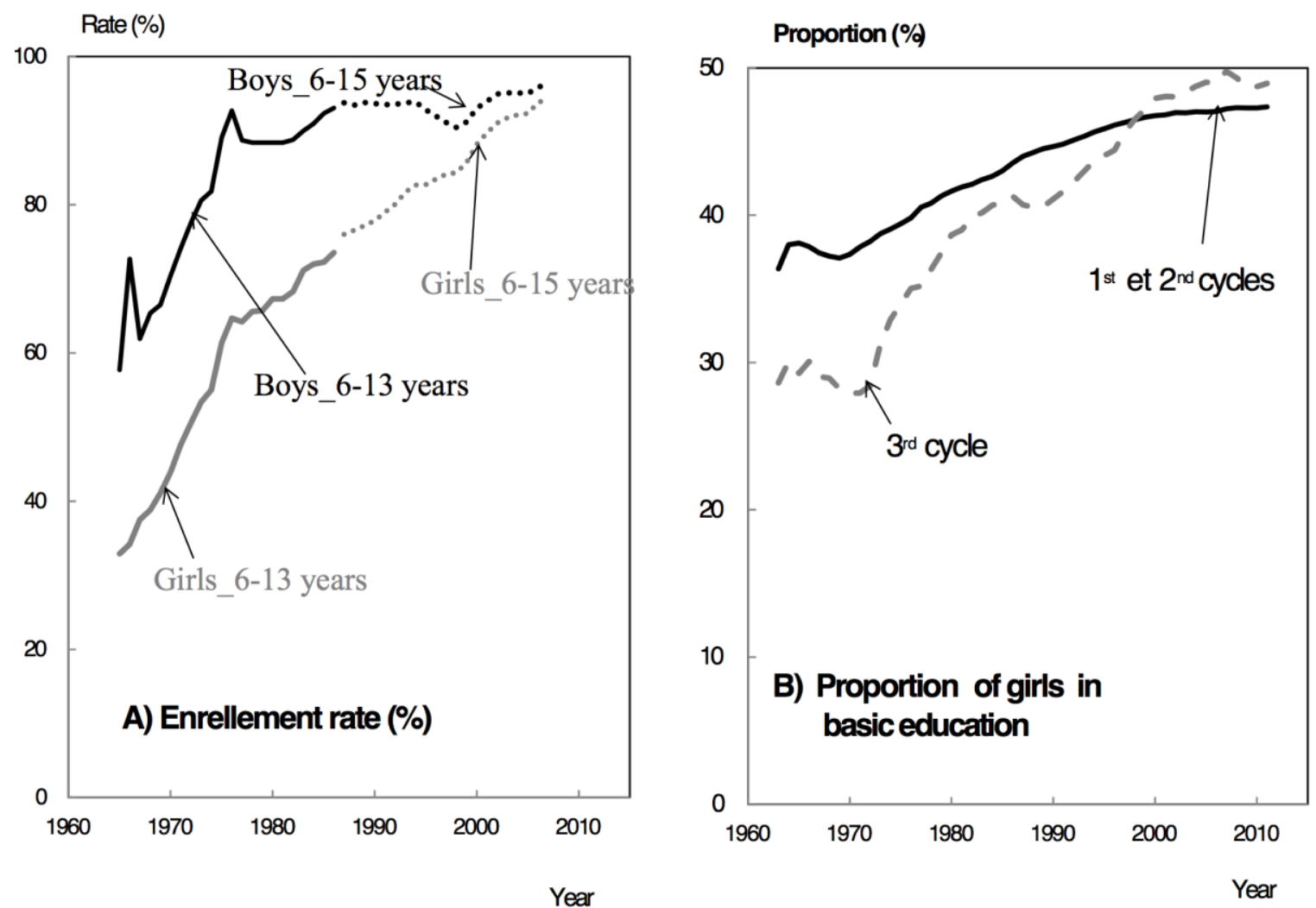

Figure 2. A) Enrollment rates for children by sex and school year. Children aged 6-13 up to 1986-87, and children aged 6-15 since 1987-88. B) Proportion of girls among enrolled students in the 3 cycles of basic $\begin{array}{lllll}\text { education } & \text { by } & \text { school } & \text { year } & \text { since }\end{array}$ Source: Retrospective of the statistics of the Ministry of Education, published by the ONS (2012)

\section{I.2 Gender inequality reversal in high school (and even more so at university)}

Moreover, because the enrollment of children aged 6-15 depends (at least in relative terms) on the enforcement of compulsory education, the evolution observed at the secondary and university levels makes this phenomenon even more evident. Since school is no longer compulsory, there is a massive drop in attendance after the age of 16, more so among boys than girls. And contrary to the gender disparities in enrollment rates before the age of 16 (which, since Algeria's independence, has become largely insignificant, but has remained slightly in favor of men), beyond this age, these discrepancies are clearly in favor of women: 5.2\% for men and women aged 15-19, and $6.6 \%$ for those between the ages of 20 and 24 in 2008 (Table 3).

Table 3. Enrollment rate (\%) by sex at ages 15-19 and 20-24 in Algeria, from 1966 to 2002

\begin{tabular}{|c|c|c|c|c|}
\hline & $1966(1)$ & $1969(2)$ & $1987(3)$ & $2002(4)$ \\
\hline & \multicolumn{5}{|c|}{ Males } \\
\hline $15-19$ & 29.8 & 29.7 & 49.9 & 44.3 \\
\hline $20-24$ & 3.2 & 8.2 & 12.9 & 11.9 \\
\hline & \multicolumn{5}{|c|}{ Females } \\
\hline $15-19$ & 9.6 & 11 & 35.8 & 49.5 \\
\hline $20-24$ & 0.5 & 1.5 & 7.8 & 15.5 \\
\hline \multicolumn{5}{|c|}{ Difference (Males - Females) } \\
\hline $15-19$ & 20.2 & 18.7 & 14.1 & -5.2 \\
\hline $20-24$ & 2.7 & 6.7 & 5.2 & -3.6 \\
\hline Sources: (1) 1966 Census (CNRES, 1974); (2) 1969 Demographic Survey (CNRES, 1974); (3) \\
\hline
\end{tabular}

In recent years, more girls than boys have attended "secondary" (i.e. high school) and "higher" (i.e. university) institutions. This evolution has been remarkable; whereas in 1963-64 girls accounted for barely one-fifth of the total number of high school students, today they account for nearly $60 \%$ (Figure 3). 
In 1995, for the first time, the number of girls enrolled in high school exceeded that of boys: out of 853,000 students, half were girls. From that point on, the proportion of girls continued to increase, finally reaching $58 \%$ in 2010 (Figure 3). This phenomenon is even more evident in attendance rates at the end of secondary school (which is validated through the baccalauréat at the end of the final year), with girls accounting for more than $62 \%$ of the students enrolled during the 2010-2011 school year (ONS, 2013).

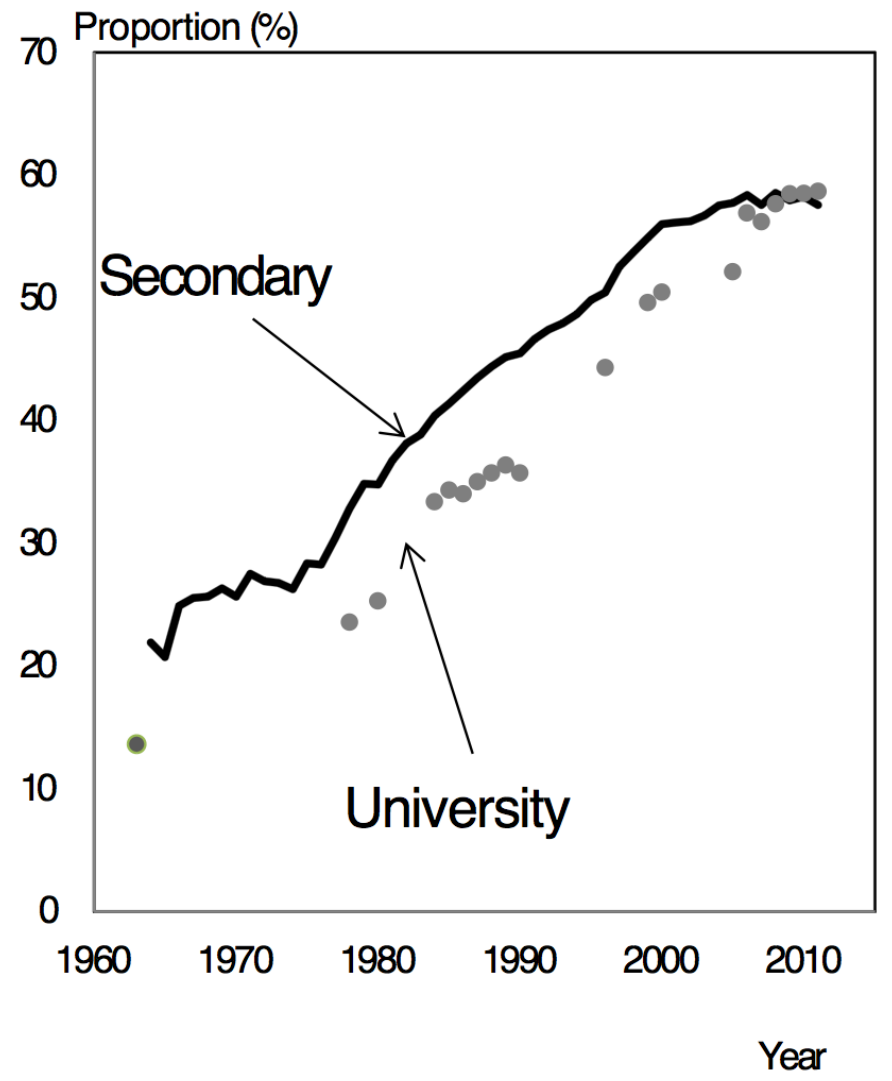

Figure 3. Proportion of girls in secondary (high school) and higher (university) institutions in Algeria since 1964

Sources: Secondary: ONS, 2012 $a$ and $b$ and 2013; University: DGPEE, 1965; CNRES, 1979; Ouadah-Bedidi, 2004 (updated using CNES, 2006); ONS, 2011, 2013)

Just as in high school, girls are more present than boys in Algeria's universities. There, they account for nearly $60 \%$ of those enrolled, compared to just $14 \%$ during the immediate aftermath of Algerian independence, and $23 \%$ during the late 1970s (Figure 3). With regard to enrollment rates, parity between girls and boys was reached in 2000 for universities, five years after it was reached for high schools. Since then, this female advantage has continued to increase.

As already mentioned above, this phenomenon is not unique to Algeria. By the early 1990s, a higher proportion of girls in higher education was observed in almost all OECD countries. By 1990, the gender gap had reversed in favor of women in 5 out of 18 countries, rising to 16 out of 18 countries by 2005 (Vincent Lancrin, 2008). The same phenomenon also appeared in Tunisia and Morocco in the early 2000s (Abdeldjalil, 2009, Alami-Mchici, 2010, Locoh and Ouadah-Bedidi, 2010, Mahfoudh, 2010). In 2010, all Arab countries counted (on average) one student in two as a woman (UNESCO, 2015). While in 2000, only 5 out of 23 Arab countries had reached (or exceeded) parity at the university level, this number rose to 7 in 2005, then to 9 in 2010 and 10 in 2011 (UNESCO, 2015). Parity was reached as early as 1999 in Bahrain, Kuwait, Lebanon, Qatar, Saudi Arabia and Sudan, followed by Algeria, Jordan and Tunisia in 2000 (Figure 4). 


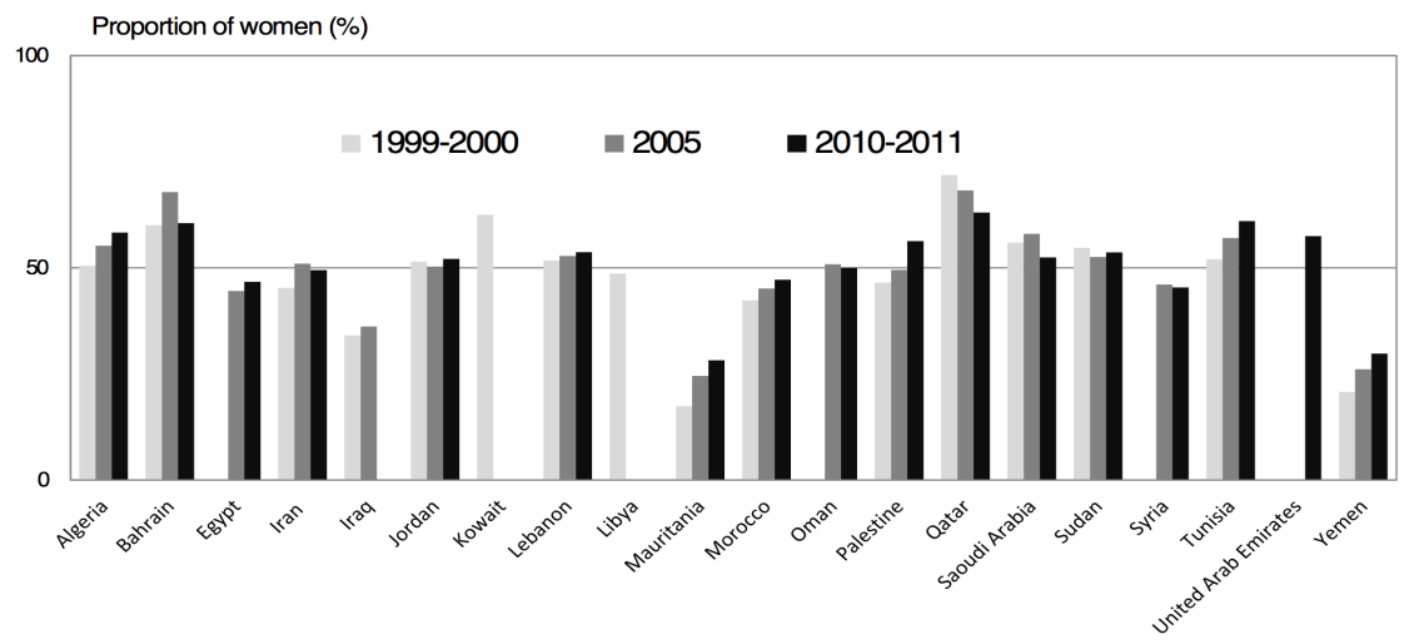

Figure 4. Proportion of women in higher education in selected Arab countries from 2000 to 2010 Source:

(UNESCO, 2015), (CNES, 2006) for Algeria (1999-2000 school year) and (INS, 2005 and 2010) for Tunisia

\section{I.2.1 More girls than boys graduate from high school}

(2011)

The higher proportion of girls in today's high schools and universities is mainly due to their higher success rates at the end of the previous cycles (the third primary cycle for entry into secondary school, and the secondary cycle for entry into university). In Algeria, the higher rates of graduation among girls have long been obscured. The data published by the Ministry of Education did not permit the retrieval of long series that could have shed light on their appearance and evolution. Even more embarrassing is the fact that since 2007, no statistics have been published on success rates for the baccalauréat or the brevet d'enseignement fondamental (a diploma which certifies nine years of primary and middle-school education). To follow the recent trends of these two indicators, one must make do with the yearly information provided by the Algerian press on the results of these two tests, which are reported by the Ministry of National Education, but never officially published. In 2005, the success rates for the brevet d'enseignement fondamental (BEF) were 38\% for girls and 35\% for boys. In 2015, they were $58 \%$ for girls and $42 \%$ for boys (Figure $5 \mathrm{~A}$ ).
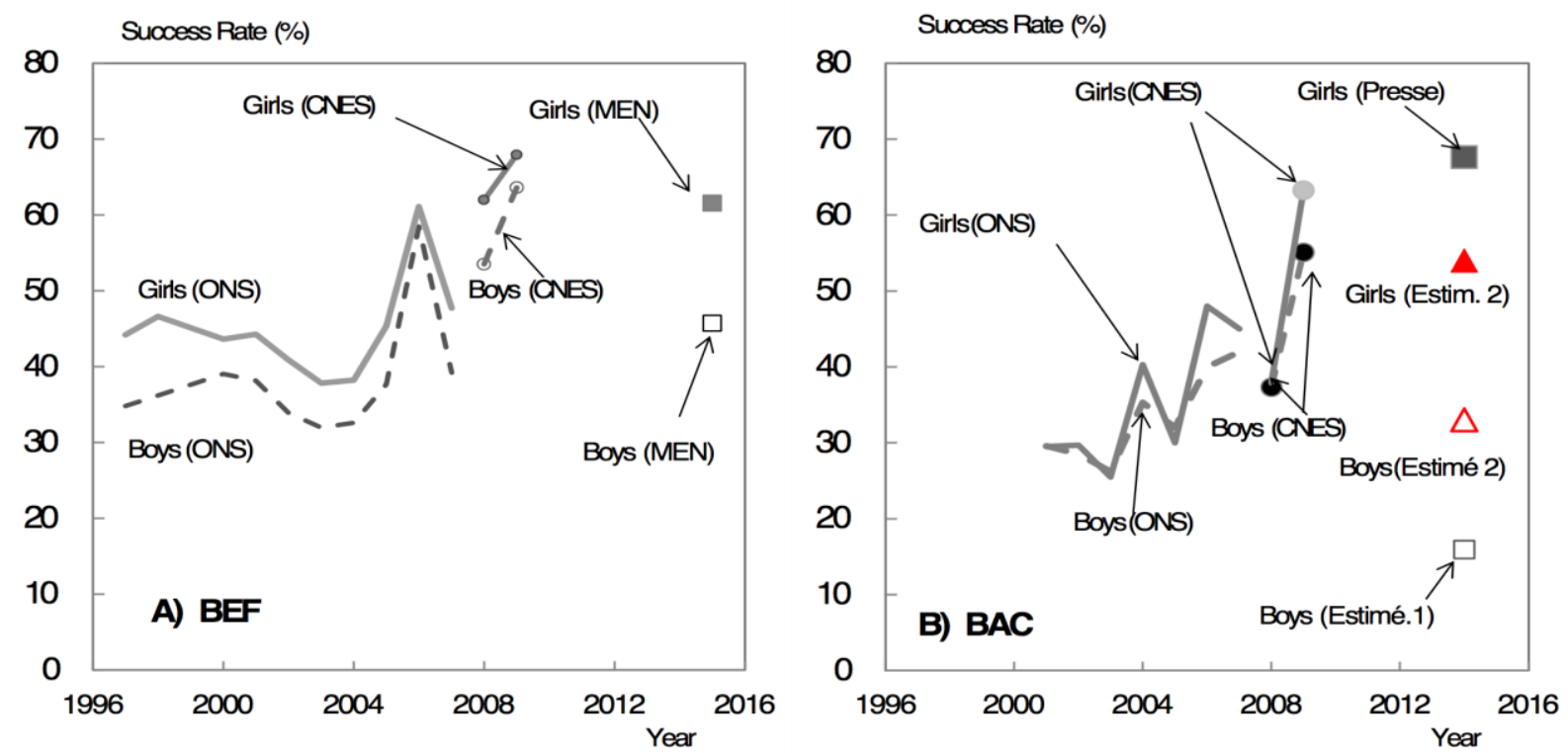

Figure 5. A) Success rate (\%) for the Brevet d'études fondamentales (BEF) and B) success rate for the Baccalauréat général (BAC) by sex. Algeria, 1997 - 2015.

Source: 1997 to 2007 ONS, different publications; 2008-2009, CNES, unpublished document; 2014 Algerian press; 2015, MEN. 
For the baccalauréat, recent changes have been even more catastrophic for boys. In 2007, the last year in which the Ministry of Education and the ONS published results by gender, $61 \%$ of the baccalauréat holders were girls (only 39\% were boys!), despite fairly similar success rates for both the general baccalauréat (43.7\% for girls and $39 \%$ for boys) and the technical baccalauréat (70\% versus $67.6 \%$, respectively). This was mainly because girls were entering high school in greater numbers than boys. Since 2007, however, the situation for boys has deteriorated dramatically in terms of success rates for the baccalauréat. It is almost certain that this is the reason why statistics are no longer published by the ONS or the MEN. Since then, the only available figures have been the bits and pieces of information published by the Algerian press based on speeches given by the Ministry of Education when the results of the baccalauréat are released. These figures show that while academic achievement among girls steadily increased between 2007 and 2014, it profoundly deteriorated for boys. By 2013, 64\% of girls passed the baccalauréat, compared to only $36 \%$ of boys. Most importantly, in 2014 the press reported an overall national success rate of $45.01 \%$, along with an exceptionally high rate for girls (67.61\%). Several attempts to find information on the success rate of boys, the number of candidates and the number of admissions to official institutions by sex have so far been unsuccessful. However, based on gender data published by the press on the number of candidates enrolled in May 2014 (APS, 30-05-2014), it is possible to reconstitute the number of girls who have passed the baccalauréat and deduce that of boys. If the published success rate of girls is correct, the success rate that can be deduced for boys is almost hard to believe: only $14 \%$ of the boys who took the baccalauréat passed ${ }^{\mathrm{V}}$. By 2014, one could then estimate that $85 \%$ of baccalauréat holders were girls!

It is actually quite probable that the so-called "success rates" published for girls are not actually success rates, but rather the proportions of girls among successful applicants. Reconstructed data would thus lead to success rates of $54 \%$ for girls and 33\% for boys, both of which are much more realistic: the gap between the sexes is less dramatic, but the female advantage has continued to grow. On the other hand, it seems that during the last few years, the level of success has reduced for both sexes, as clearly indicated by the last National Report on Human Development (CNES, 2016).

It is clear that without more detailed information, the drop in success rates for boys will remain unexplained: were official rates overestimated in the years leading up to 2007? Were there errors in the statements made by the press? Why has the Ministry of Education ceased to publish basic statistics since 2007?

\section{I.2.2 More girls attending university}

As success rates for girls far surpass those of boys, more girls than boys are also attending university. During the 2011-12 school year, 60\% of the 1,090,592 students on track to graduate ${ }^{\mathrm{vi}}$ from Algerian universities were girls (ONS, 2013). The proportion of girls at university, barely 10\% during the 1981-82 school year, rose to $50 \%$ in the early 1990s (Acherrar, 1996), reaching nearly 60\% by the 2010-11 school year (ONS, 2012). Girls are now found in all areas of study, even those that once seemed to be reserved exclusively for boys. Post-graduation, they have made up half of the students enrolled in university over the last decade, compared to 36\% in 1993-94. Certain areas of study have become more female-oriented than others: in 2010-2011, for example, there were 148 girls per 100 boys in the natural and earth sciences, 140 in literature, and 133 in the medical sciences.

When it comes to university degrees, the female advantage is just as evident. Since the 2009-10 school year, nearly 2 out of 3 graduates have been girls in all areas of study combined. In some disciplines, girls represent an overwhelming majority, making up $65 \%$ of graduates in medicine, the social sciences, and the humanities, $80 \%$ in the natural and earth sciences, and $83 \%$ in languages. Even in a previously male-oriented discipline like "the hard sciences", girls are doing much better than boys, (68\% in 2009-10 and 70\% in 2010-11) (Table 4). Only "applied sciences", "technology" and "veterinary" remain male-oriented. 
Table 4. Proportion of girls enrolled in university, and of students holding university degrees, by discipline, from 2004-05 to 2010-11

\begin{tabular}{|l|llllllll|}
\cline { 2 - 8 } \multicolumn{1}{c|}{} & $\mathbf{2 0 0 4 - 0 5}$ & $\mathbf{2 0 0 5 - 0 6}$ & $\mathbf{2 0 0 6 - 0 7}$ & $\mathbf{2 0 0 7 - 0 8}$ & $\mathbf{2 0 0 8 - 0 9}$ & $\mathbf{2 0 0 9 - 1 0}$ & $\mathbf{2 0 1 0 - 1 1}$ \\
\hline Enrolled in university & $\mathbf{5 6 . 9}$ & $\mathbf{5 6 . 1}$ & $\mathbf{5 7 . 6}$ & $\mathbf{5 8 . 5}$ & $\mathbf{5 8 . 5}$ & $\mathbf{5 8 . 7}$ & $\mathbf{5 8 . 8}$ \\
On track to graduate $\left.*^{*}\right)$ & $\mathbf{5 7 . 4}$ & $\mathbf{5 6 . 7}$ & $\mathbf{5 8 . 3}$ & $\mathbf{5 9}$ & $\mathbf{5 9}$ & $\mathbf{5 9 . 3}$ & $\mathbf{5 9 . 5}$ \\
\hline Graduated by Discipline & $\mathbf{6 1 . 1}$ & $\mathbf{6 0 . 4}$ & $\mathbf{6 0 . 4}$ & $\mathbf{6 1 . 1}$ & $\mathbf{6 3 . 4}$ & $\mathbf{6 5}$ & $\mathbf{6 4 . 7}$ \\
HardSciences & 64 & 60.6 & 60.6 & 61.7 & 64.2 & 67.7 & 70.5 \\
Applied Sciences & 48.9 & 45.9 & 45.9 & 28.4 & 32.2 & 38.7 & 30.8 \\
Technology & 37.2 & 35.9 & 35.9 & 36.6 & 34.8 & 36.2 & 35.9 \\
Medical Sciences & 58 & 59.8 & 59.8 & 61.6 & 62.4 & 66.4 & 65.3 \\
Verterinary Sciences & 52.3 & 42.9 & 42.9 & 45 & 45.3 & 48.6 & 44.1 \\
Natural/Earth Sciences & 73.1 & 76.5 & 76.5 & 73 & 73.8 & 76.9 & 80 \\
Social/Human Sciences & 60.8 & 61.9 & 61.9 & 61.4 & 63.8 & 65.9 & 65 \\
Language and Literature & 83.7 & 79.2 & 79.2 & 82.3 & 82 & 83.8 & 82.6 \\
\hline Sources: ONS, based on statistics from MESR. Years 2004-05 and 2005-06 (ONS, annual report no. \\
26; years 2007-O8 to 2010-11(ONS, annual report no. 29) \\
(*)Graduation : the first university degree after three years of studies & & & \\
\hline
\end{tabular}

Is this extraordinary increase of women in higher education, which has been proven on a national scale, true everywhere? Or do these figures efface geographical disparities?

\section{IS THIS GENDER REVERSAL GENERAL, OR DOES IT OVERSHADOW GEOGRAPHICAL DISPARITIES?}

It would be interesting to study two kinds of geographical disparities: the difference between town and country, which is closely related to lifestyle and other socio-economic factors, and disparities between territories, which strongly reflect the influence of regional characteristics. Unfortunately, the data that can be used to measure these disparities is scarce. Departmental statistics on educational achievement are not regionalized. Because they ask questions about the respondents' "last class taken", "individual situation" (with "student" as a possible answer), and "highest diploma obtained", censuses could also be an important source of information. However, the answers to these questions are rarely published by age, gender and geographical location, and the question asking the highest diploma received was struck from the country's most recent census (2008). Moreover, in the 2008 census (as in the one before it), the use of the question on the respondents' individual situation did not make it possible to measure enrollment rates beyond the age of 14. Finally, for the most recent period, the only question providing useable data is the one on the last class taken. This question makes it possible to calculate the proportion of people who have received at least one year of "primary" (first and second cycles), "middle" (third cycle), "secondary" (high school) and "higher" (university) education. Unfortunately, this data has not been studied at the residential (urban / rural) level. The most recent source is the 2002 PAPFAM survey, and if one wants to compare the most recent situation with past situations, only the 1987 census (for which data has been found in archives) can be used due to its accessibility and comparability.

\section{II.1 The female advantage: an urban phenomenon}

As far as enrollment rates (proportions of pupils or students in a given age group) are concerned, the advantage of women is not just recent, but also almost exclusively urban.

\section{II.1.1 Enrollment rates: from the male rural advantage to the urban female advantage}

Since the advantage of women is not apparent beyond the ages for which school is compulsory, attention will be 
paid to the three following age groups: 15-19, 20-24 and 25-29. Table 5 compares the situation observed in the 1987 census with that which was revealed in the 2002 PAPFAM survey for these three age groups (each spanning five years). In 1987, at age 15-19, the male advantage was significant in rural areas, with almost $40 \%$ of boys enrolled in school compared to only $17 \%$ of girls - a gap of nearly 23 percentage points. With enrollment rates for boys considerably higher than those for girls (59\% and 52\%, respectively), the male advantage was less marked, but still significant in urban areas (7 points). In both rural and urban areas, this gap was naturally much lower at 20-24 and 25-29 years, as the rates themselves were much lower. In relative terms, the male advantage was just as high, but the disparity between cities and countryside was less significant. Everywhere, the advantage of men was most evident at the ages that typically corresponded to university studies.

Table 5. Enrollment rate (\%) by sex, age group, and place of residence in Algeria in 1987 and 2002

\begin{tabular}{|c|c|c|c|c|c|c|c|c|c|}
\hline & \multicolumn{3}{|c|}{ Urban } & \multicolumn{3}{|c|}{ Rural } & \multicolumn{3}{|c|}{ Total } \\
\hline & Male & $\begin{array}{l}\text { Fema } \\
\text { le }\end{array}$ & Difference $(*)$ & Male & Female & Difference $(*)$ & $\begin{array}{l}\text { Mal } \\
\mathrm{e}\end{array}$ & Female & Difference $(*)$ \\
\hline & \multicolumn{9}{|c|}{ RGPH 1987} \\
\hline $15-19$ & 58.9 & 52.0 & 7.0 & 39.6 & 16.9 & 22.7 & 49.9 & 35.8 & 14.1 \\
\hline $20-24$ & 17.7 & 12.2 & 5.5 & 7.3 & 2.2 & 5.2 & 12.9 & 7.8 & 5.1 \\
\hline \multirow[t]{2}{*}{$25-29$} & 3.9 & 2.1 & 1,8 & 1.1 & 0.3 & 0.8 & 2,6 & 1.2 & 1.4 \\
\hline & \multicolumn{9}{|c|}{ Enquête PAPFAM 2002} \\
\hline $15-19$ & 52.3 & 63.4 & -11.1 & 43.2 & 36.7 & 6.5 & 48.2 & 51.9 & -4.3 \\
\hline $20-24$ & 16.9 & 23.9 & -7.0 & 9.4 & 9.3 & 0.1 & 13.7 & 17.8 & -4.9 \\
\hline $25-29$ & 3.5 & 3.5 & 0.0 & 1.5 & 0.8 & 0.7 & 2.8 & 2.4 & 0.4 \\
\hline \multicolumn{10}{|c|}{$\begin{array}{l}\text { (*) Difference = Male }- \text { Female (in percentage points) } \\
\text { Source: 2002: taken from the PAPFAM survey by the author (question } 113 \text { on individual } \\
\text { situation ("household" section); 1987: taken by the author from the archives of } 1987 \text { census } \\
\text { (unpublished). }\end{array}$} \\
\hline
\end{tabular}

Conversely, according to the 2002 PAPFAM survey, the situation in the city had become very different from that in the countryside (Table 5). While in rural areas, the male advantage (although greatly reduced) persisted in the three age groups, in urban areas, girls were more likely than boys to pursue their education once it was no longer compulsory. In the 15-19 age group, the enrollment rate for girls was 11 points higher than that of boys. Unsurprisingly, this was due not only to the sharp increase in the female enrollment rate from $52 \%$ to $63 \%$, but also to a decline in the male enrollment rate from 59\% to 52\%. The success of the girls was thus set against the failure of their male classmates, a phenomenon that was also apparent in the 20-24 age group (which reflected a doubling of the female enrollment rate alongside a decline of the male enrollment rate) as well as in the 25-29 age group. It should be noted, however, the fact that a student is enrolled at a given age does not necessarily imply that that said student will complete the level of education corresponding to their age.

\section{II.1.2 Level of educational attainment: a confirmation of the urban female advantage}

Using the answers to the question "last class followed", Table 6 provides the differences between the proportion of men with a given level of education, and that of women who have reached the same level of education. In 1987, the male advantage was clear at all ages, at both levels of education identified in the survey ("secondary" and "higher"), and in both urban and rural areas. By 2002, however, the scales had clearly tipped in favor of women of all ages in urban areas, both at the secondary and higher levels. This advantage was particularly marked at the secondary level in the 15-19 age group. Thus, not only were girls of this age significantly more educated than their male classmates (as discussed in the previous table), they also continued their education beyond secondary schooling. 
And, of course, at the higher level, we can see that this was also the case in the 20-24 age group. In other words, in urban areas, women in a given age group were far more likely than men to have attained the level of education normally associated with their age. It is clear that as early as 2002, girls living in cities were receiving a better education than their male counterparts. Table 6 also shows that even in rural areas, girls aged 15-19 were more likely than boys to have reached secondary (or even higher) levels, although this was not yet the case among older age groups.

Compared with the results in Table 5, these figures show that although in 2002, rural girls were still less educated than boys in the age groups after compulsory education, they had already attained the level of education corresponding to their age (15-19) at a higher rate than their male counterparts.

Table 6. Difference in the proportion of males that have attained a certain level of education, and that of females who have attained the same level of education, by place of residence, in 1987 and 2002

\begin{tabular}{|c|c|c|c|c|c|c|}
\hline & \multicolumn{2}{|c|}{ Urban } & \multicolumn{2}{|c|}{ Rural } & \multicolumn{2}{|l|}{ Total } \\
\hline & 1987 & 2002 & 1987 & 2002 & 1987 & 2002 \\
\hline & \multicolumn{6}{|c|}{ Secondary } \\
\hline $15-19$ & 2.3 & -12.7 & 11.9 & -1.7 & 6.6 & -7.9 \\
\hline $20-24$ & 2.7 & -4.6 & 8.6 & 4.9 & 5.2 & -0.6 \\
\hline \multirow[t]{2}{*}{$25-29$} & 6.8 & -1.7 & 7 & 12 & 6.9 & 4.3 \\
\hline & \multicolumn{6}{|c|}{ Higher } \\
\hline $15-19$ & 0.3 & -4.1 & 0.4 & -0.6 & 0.3 & -2.5 \\
\hline $20-24$ & 4.2 & -9 & 3.9 & 1.8 & 4 & -4.5 \\
\hline $25-29$ & 5.3 & -3 & 3.5 & 2.2 & 4.4 & -0.7 \\
\hline
\end{tabular}

\section{II.2 The female advantage: a highly regionalized phenomenon}

When it comes to measuring the geographical diversity of the gender gap in education, the only useful data available are the answers to the question about the "last class taken" in the 1987 and 2008 censuses. As with the urban / rural difference, here we will simply distinguish those who have acquired a secondary level of education, and those who have acquired a higher level of education. In order to avoid an excessively long analysis, we will focus on the acquisition of a secondary education in the 15-19 age group that corresponds to this level, and the acquisition of a higher education in the 20-24 age group, as this is also the time during which most go to university. Since the necessary data is only available at the wilaya level, the following analyses cover the 48 wilayas in Algeria. Wilayas are Algerian administrative districts that can be roughly equated to the French département. The organization of these administrative districts changed very little between 1987 and 2008, which makes it possible to compare the administrative topography of the two periods.

\section{II.2.1 Acquisition of the "secondary" level at 15-19 years}

In 1987, the 15-19 age group saw $28.7 \%$ of its male students complete at least one year of high school, compared to $21.1 \%$ of its female students - a male advantage of 6.6 points. Twenty years later, in the 2008 census, this proportion had dropped to $23.9 \%$ for boys and increased to $31.3 \%$ for girls, completely reversing the difference to the advantage of the latter, bringing the male-female difference to -7.4 percentage points. It is this indicator that we will map using the current administrative topography (2008), and examine how it has changed since 1987.

In 2008, in 47 of the 48 wilayas, the difference between men and women was negative, and in the 48th, Djelfa, there was zero difference. We can therefore draw the conclusion that the inversion of the male advantage in favor of women has been a general phenomenon throughout the Algerian territory. 
However, this change has been far from uniform; in 10 wilayas, the difference is less than 5 points, whereas in 9 wilayas, the difference lies somewhere between 10.1 to 13.9 points (Appendix 2). These numbers reflect strong geographical differences: the 14 wilayas where the difference is greater than 9 (Tizi Ouzou, Boumerdes, Constantine, Algiers, Jijel, Blida, Guelma, Annaba, El Tarf, Mila, Tipasa, Bejaia, Skikda and Bouira) all form a line, running from the wilaya of Algiers towards the northeast, extending all the way to the Tunisian border (Figure 6).

In 1987, only 4 wilayas showed a female advantage by a few points (Algiers, Annaba, Constantine and Oran), and in 18 wilayas, the difference in favor of boys was more than 9 points (Appendix 3 and Figure 7). The topography of inequalities was therefore the same as today, with girls being less disadvantaged in the Northeast than in the rest of the country. Let us note, however, a significant nuance: Oran, one of the 4 wilayas where the girls surpassed the boys in terms of education, is no longer in the lead today. It seems that in 1987, the divide was more urban / rural (the 4 largest cities against the rest of the country) than regional. Today, the opposition between the North and the East is most apparent (Algérois, Kabylie, Constantinois).

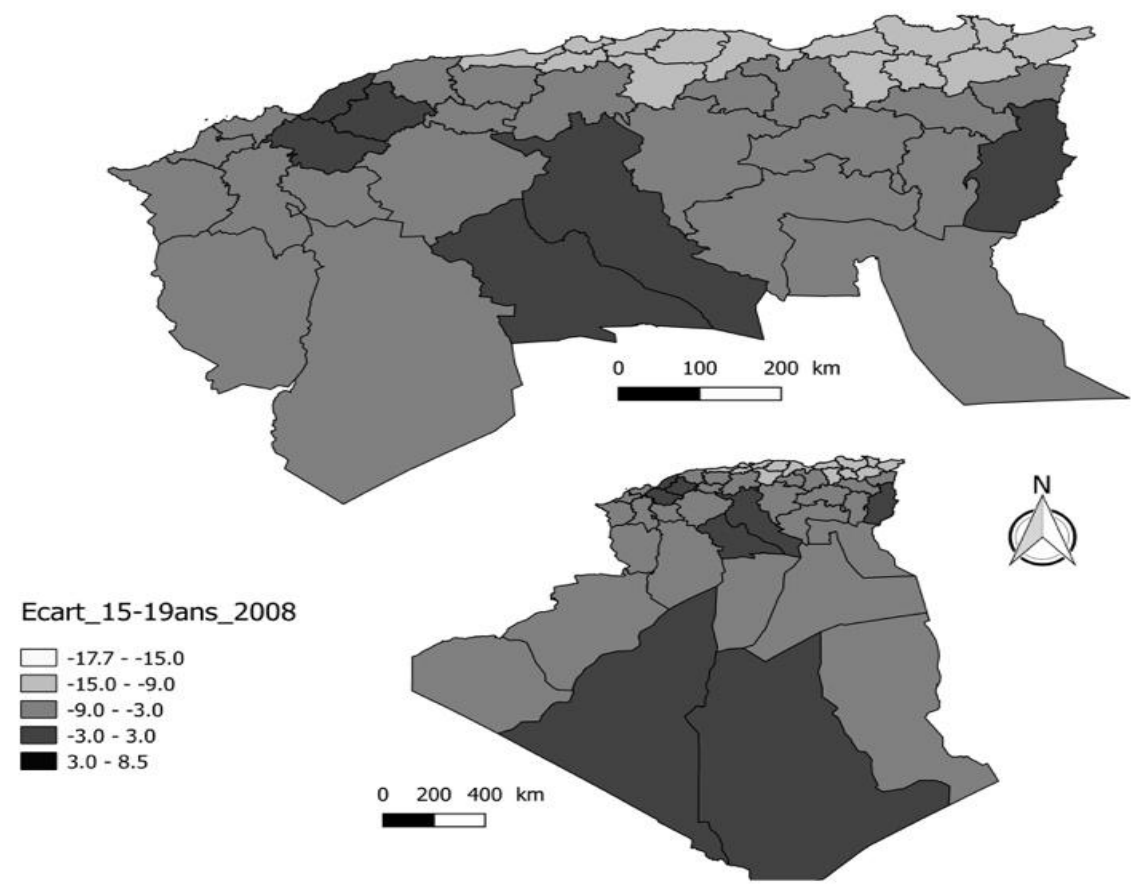

Figure 6. Geographical variations of the difference in male and female proportions $(\%)$ among those in the 15-19 age group with a secondary education (at least one year of high school) according to the 2008 census. 


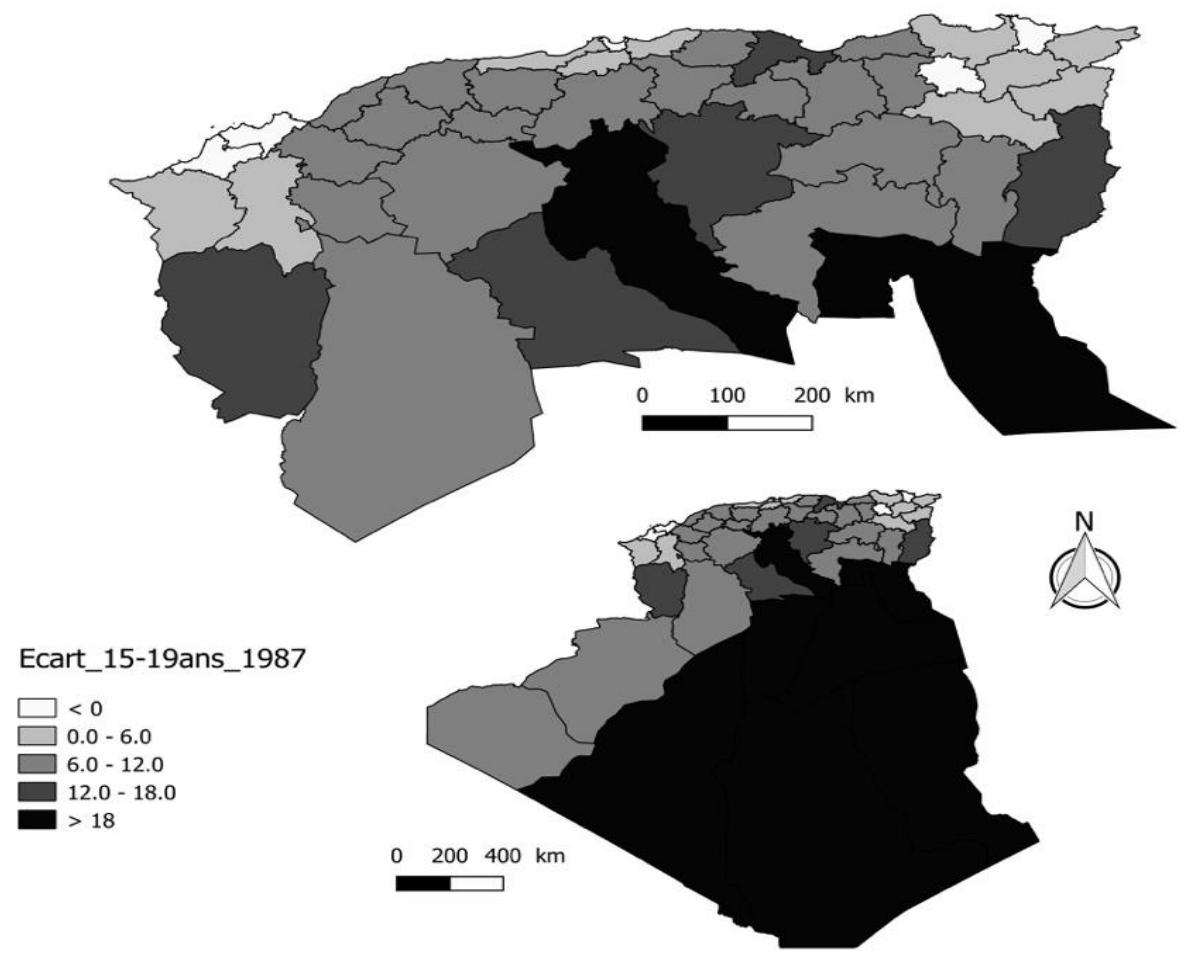

Figure 7. Geographical variations of the difference in male and female proportions $(\%)$ among those in the 15-19 age group with a secondary education (at least one year of high school) according to the 1987 census. II.2.1 Acquisition of "higher" education (20-24 years)

In 2008, in the 20-24 age group, only $15.2 \%$ of men had completed at least one year of university in Algeria, compared with $24.4 \%$ of women, a difference of 9.2 points in favor of women (ONS, 2012). This presented a dramatic reversal, since in 1987, these proportions were $9.8 \%$ for men and $5.8 \%$ for women, with a difference of 4.0 points in favor of men.

The topography of this gap (Figure 8) is very similar to that which we observed for secondary education in the 1519 age group, and twice as reinforced. With regard to the level of education attained, the absolute difference exceeds 15 points in four wilayas. This difference is all the more spectacular because the proportions involved are much smaller. In Constantine, for example, where the proportion of girls between the ages of 15 and 19 with a secondary education was half that of boys (36\% versus $24 \%$ ), the proportion of girls aged 20-24 with a higher education is twice that of boys ( $36 \%$ vs. 18\%). It should be noted that in this wilaya, the proportions of girls in higher education at 20-24 years of age is the same as the proportion of girls aged 15-19 in secondary school, which could indicate that the majority of girls who have a secondary education continue their studies into university. This geographical topography in favor of women is also reinforced in the 20-24 age group in the sense that more wilayas are marked by a very pronounced female advantage. In 21 of the 48 wilayas, the difference here is in favor of women by more than 9 points (compared to only 14 wilayas at 15-19 years of age), while 3 southern wilayas (Adrar, Ghardaia and Djelfa) consistently reflect a male advantage (compared to none at 15-19 years). 


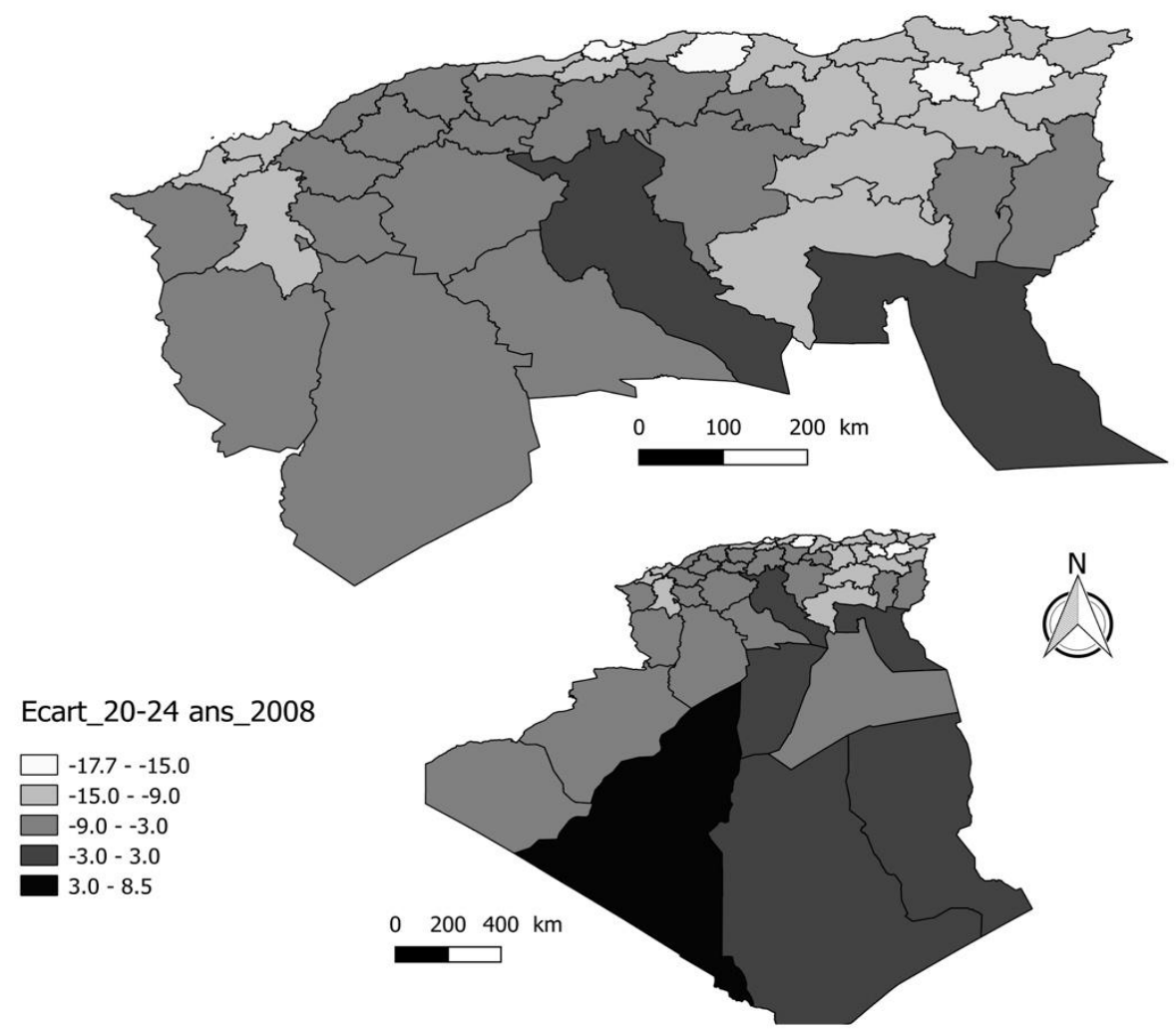

Figure 8. Geographical variations of the difference in male and female proportions (\%) among those in the 20-24 age group with a higher education (at least one year of university)

\section{WHY HAVE THESE DISPARITIES REVERSED IN “SECONDARY” AND “HIGHER" EDUCATION ?}

Why do Algerian women go further in their studies and do better in school than their male counterparts? One reason could be the prioritization of girls' education, namely through the creation of compulsory and free basic education. That this has led to a rise in girls' attendance rates (which now nearly reach those of boys) has been an expected result; that girls would also become more educated than boys overall, however, is a surprise. In Europe, studies that have analyzed the reasons for such success have combined the factors of female socialization, which teaches the values of submission, order, and obedience at a young age, and makes girls good students early on in their schooling, and the fact that girls are more likely than boys to plan for their future careers and chances of success (Caspard, 2007).

On the other hand, several studies that have analyzed the consequences of the reversal of gender inequalities in education on marriages have also concluded that hypergamy (in the educational sense) is less and less common (Estève, 2012, 2016, Valat, 2015).

In Algeria, aside from the policies that have been put into place to ensure that primary school, then high school and university, are as accessible to girls as they are to boys, and the resistance that many girls experience, whether from their families or because of their socio-economic situation, two additional factors also have an influence on the male-female difference in education: the given student's motivation, and his or her ability to succeed. Unfortunately, there is no comprehensive study of the overall factors that contribute to school attendance and success. It is possible, however, to better understand the subject by analyzing the answers to two questions posed in the only representative survey that has ever examined the reasons for low rates of school attendance and high dropout rates: the 2002 PAPFAM survey.

Two questions in the survey address this topic. The first was posed (in the questionnaire) to all of the respondents aged 6-14 vii. The second question was posed to a representative sub-sample of young, unmarried adults aged 15-29viii.

The first question is of relatively little interest, as it is addressed to the age group for which education is compulsory: by this age, girls have largely caught up with boys, since their parents are legally obligated to send them to school. The answers given by 14-year-olds, however, may be relevant to our study, as this is the age at 
which children begin to make the transition into high school after the brevet d'études moyennes (BEM) and the brevet d'études fondamentales (BEF) exit exams ${ }^{\mathrm{ix}, \mathrm{x}}$. Out of the 3126 14-year-olds surveyed, more than $16 \%$ were not enrolled in school in 2002 (5\% had never attended school in the first place, and $11 \%$ had dropped out of school early), with girls being slightly more affected by this phenomenon than boys. For these children, their parents gave no reason for their children dropping out of school in nearly $40 \%$ of cases, especially when it came to girls. When a reason was given, however, failure in school was cited the most often, and was given as an explanation for boys much more frequently than for girls. The second most common reason, distance from school, affected only slightly more girls than boys, and the third, parental support, mainly affected boys (Figure 9).

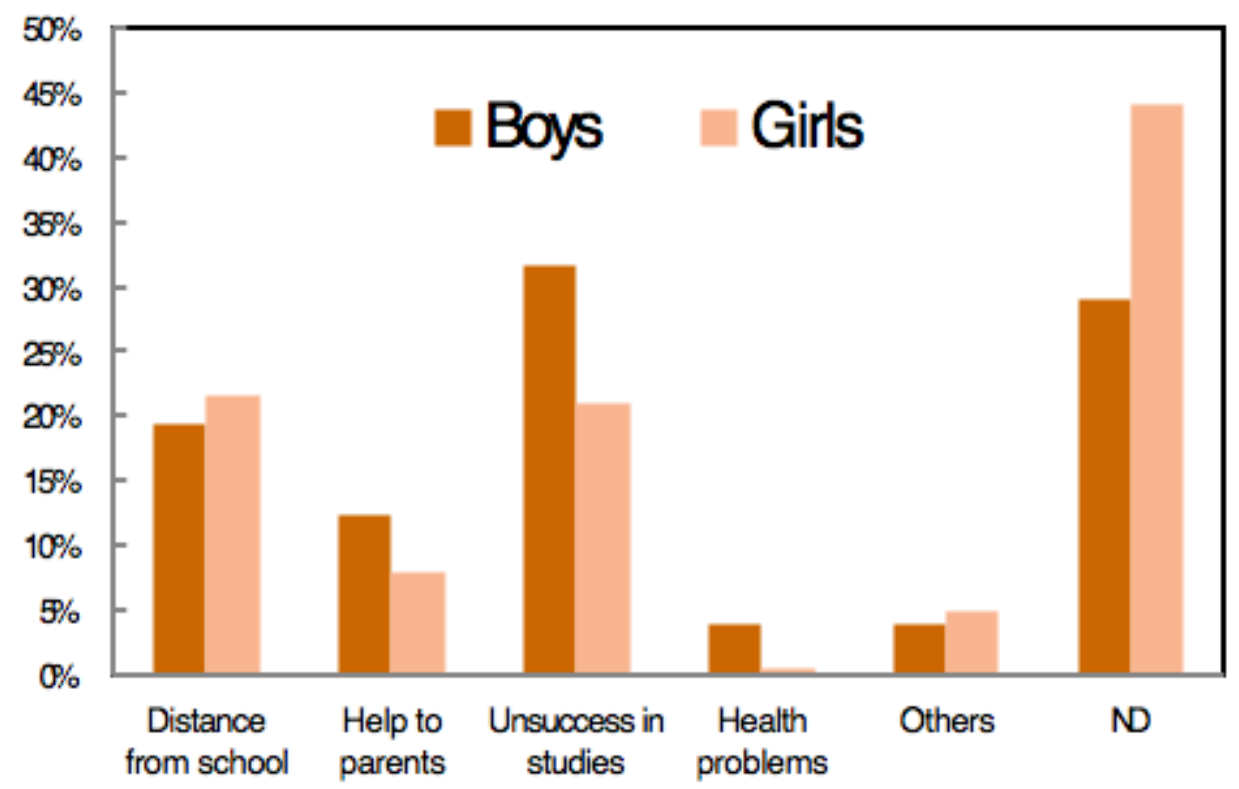

Figure 9. Reasons for dropping out of school (for 14-year-olds), by sex Source: Author's use of question \#111 of the PAPFAM household questionnaire, "What is the main reason why (NAME) dropped out of school?", posed to each child who had attended school in the past, but was no longer in school at the time of the survey.

The second question is more relevant to our analysis due to its target: young people aged 15-29, most of whom are no longer obligated to attend school. Our analysis is limited, however, by the fact that the question was only posed to unmarried young men and women.

The expulsion of married students almost only happens to men, and can thus seriously bias the results of such a study. For this reason, analysis should focus on respondents aged 15-19, as they are less likely to be married. Again, respondents who had attended school in the past, but were no longer enrolled at the time of the survey, were asked why they had left middle school or high school. While we are obviously unable to know the full extent of the reasons why girls are more numerous in high school and more likely to earn their baccalauréat than boys, here we will attempt to at least shed some light on the causes for these phenomena.

The studied sub-sample consists of 762 men and 838 women, all aged 15-19. The abnormally low number of men in school (at least compared to women) is largely due to the undercount of those who have left school to serve in the military. Nevertheless, the proportions of men who have reportedly never attended school (2\%) or have dropped out of school (48\%) underestimates the reality of these numbers, while the proportion of those in school $(50 \%)$ is an overestimate. Even so, the proportion of women enrolled in school is still higher than men according to the survey (51\%), though the proportion of women who have never been enrolled (9\%) is significantly higher than that of boys. Thus, despite this lack of complete access to schooling, in 2002 girls were already more educated than their male counterparts in the age groups for which schooling was no longer compulsory. This is due to the fact that girls drop out of school less often than boys (40\%, compared to an underestimated $48 \%$ for boys). 
Of the girls aged 15-29 who were enrolled in school at the time of the survey, $11 \%$ were already attending university, whereas the proportion of boys attending university was only half that $(5.5 \%)$. Nearly $60 \%$ of girls were enrolled in high school (compared to $50 \%$ for boys), but the proportions reversed in middle school (30\% for girls, compared to $45 \%$ for boys), and primary school ( $0.5 \%$ for girls, compared to $3 \%$ for boys) (Figure 10$)$. Thus, the survey confirms that as of 2002, girls in this age group were better educated than boys due to their higher rates of attendance and their lower likelihood of having delayed their studies.

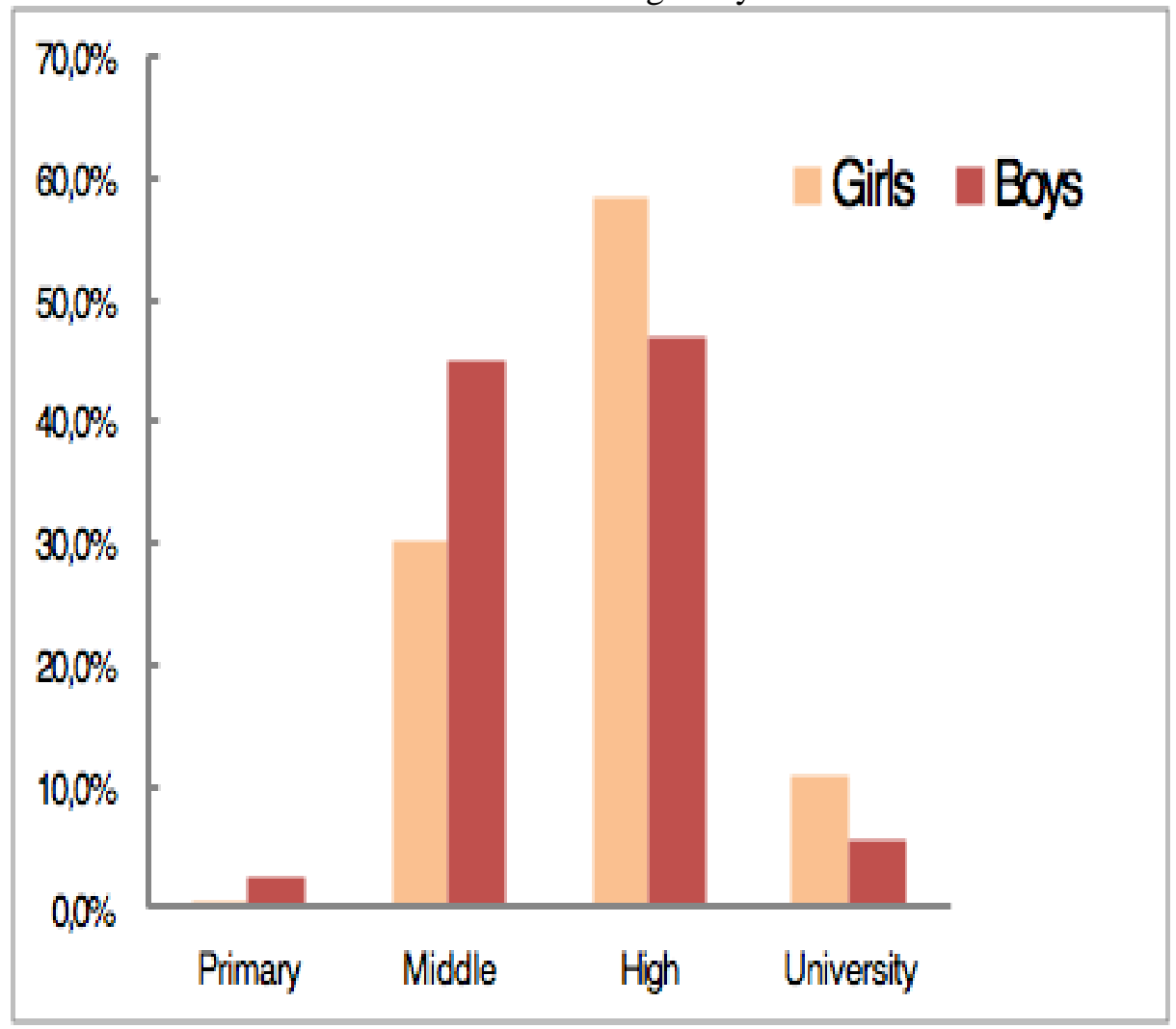

Figure 10. Proportions of unmarried persons aged 15-19 attending school in 2002, by level of education

The question posed about the reasons for dropping out of school yielded 18 different types of answers (ONS, 2004). In order to avoid overcomplicating analysis with a large number of small proportions, these types of answers have been regrouped into the 7 following categories:

\begin{tabular}{|c|c|}
\hline Category & Reasons \\
\hline Lack of motivation & $\begin{array}{l}\text { Respondent considers that they have achieved the desired level of education; } \\
\text { respondent does not wish to continue his or her studies }\end{array}$ \\
\hline Educational difficulties & Respondent has not succeeded in his or her studies; school is too difficult \\
\hline \multicolumn{2}{|l|}{ Expelled from school } \\
\hline Distance from school & School is too far away \\
\hline $\begin{array}{l}\text { Left school to help his } \\
\text { or her family }\end{array}$ & $\begin{array}{l}\text { Family does not want to pay for respondent's tuition or other educational fees; } \\
\text { respondent must help around the house; respondent works to support his or her } \\
\text { family; respondent assists the family in business or agricultural duties }\end{array}$ \\
\hline Opposition from family & $\begin{array}{l}\text { Respondent's family considers that they have achieved their desired level of } \\
\text { education; family is against the pursuit of education for girls; family is against the } \\
\text { pursuit of education of general; family is against mixed-gender schools; respondent } \\
\text { is preparing for marriage. }\end{array}$ \\
\hline Other & Health problem(s); mistreatment by teachers and instructors; other \\
\hline
\end{tabular}

In analysing these responses, one can divide the respondents into two groups: those who reached the middleschool level without continuing into high school, and those went to on reach the secondary level. 
At the middle-school level, the most common reason for dropping out of school was failure in school. Of the three different types of failure considered here, "educational difficulties" was the most commonly cited, with little difference between boys and girls (Figure 11, left). On the other hand, the two other types of failure ("lack of motivation" and "expelled from school"), were cited as the reason for failure in school for boys much more often than for girls ( $83 \%$, compared to 69\%). In secondary school, failure is less differentiated by gender. There does, however, seem to be a greater lack of motivation among boys, whereas girls are expelled more frequently than their male counterparts.

Among the other reasons for dropping out of school, there are two which almost exclusively affect girls: distance from school, and parental opposition, both at the middle school and high school level. Financial difficulties ("left school to help his or her family"), which also affect both sexes at the middle-school level, only seem to affect boys at the secondary level. In reality, girls are more likely to drop out of school in order to help their families with household duties, whereas boys are more likely to drop out of school in order to work and contribute to the resources of the family. The economic crisis of the 1980s, and the dark decade of civil war, increased the economic stability of many households, thus creating a climate of insecurity for many citizens, particularly those living in rural areas. In this context, boys have since been under more pressure than girls to leave school at the age of 16 (the age at which school is no longer compulsory, as well as the minimum age to legally work) to look for work or help contribute to the family's finances. For girls, problems of financial instability have worsened the dropout rate of girls who move far away from their school.

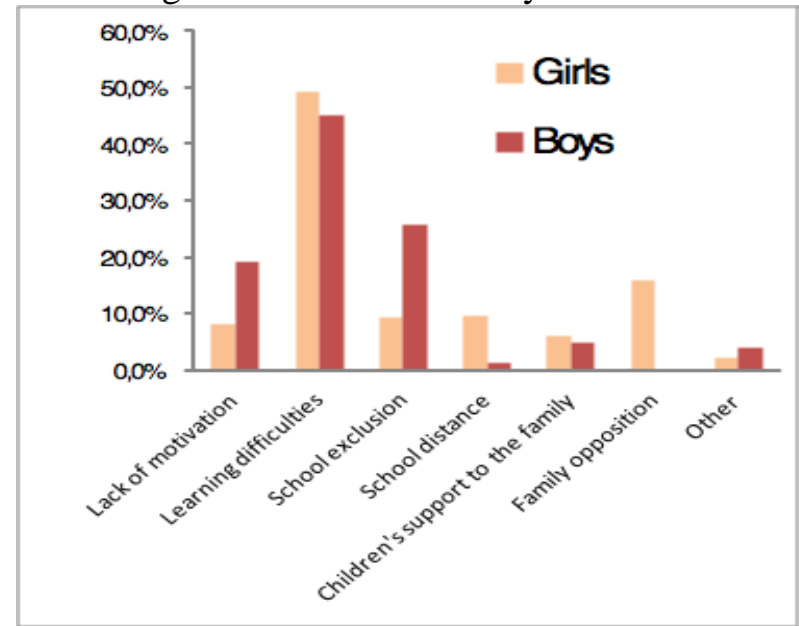

Middle School

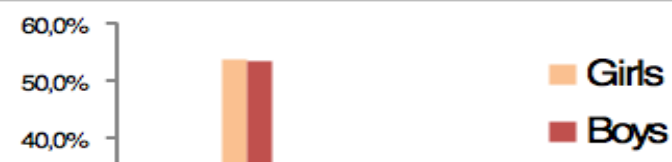

$30,0 \%$$$
20,0 \%
$$

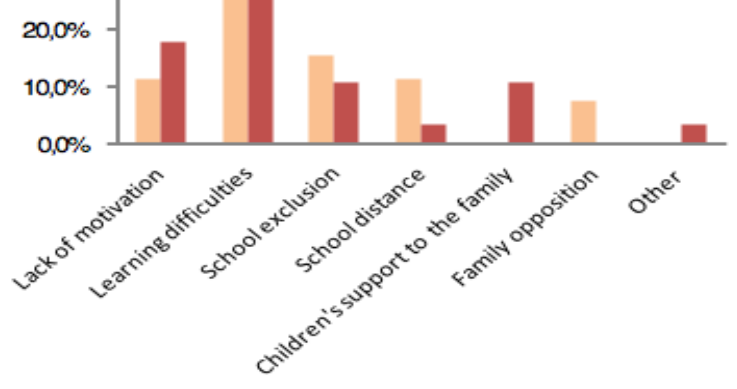

Secondary/high School

Figure 11. Reasons for dropping out of school for young, unmarried adults aged 15-19, by level of education

\section{Overview and conclusion}

Since the late 1990s, Algerian women have emerged as the main beneficiaries of the active policy pursued by all the successive Algerian governments since independence in order to make education accessible to all. As in France, basic education is free and compulsory up to the age of 16, and institutions of secondary and higher education are widely accessible at affordable costs. This initiative has always adopted a policy of nondiscrimination between the sexes, and, as expected, provided basic education to nearly all of Algeria's children, both boys and girls, and offered them the possibility of catching up and closing the considerable educational lag the country suffered in the aftermath of independence. What was not expected, on the other hand, was that for nearly 20 years, more girls than boys would enter into high school and university. While this phenomenon manifested in cities and the leading wilayas in terms of economic development, it quickly gained traction and spread throughout the territory. Everywhere, girls now have higher rates of enrollment than boys, and are more likely continue their education beyond the age of compulsory education that their male classmates.

Furthermore, not only do more girls now attend higher secondary schools and universities than boys, but they also perform better in their studies, a phenomenon which seems to start in primary school. Over the course of their education, regardless of age group, more girls than boys have achieved the level of education corresponding to 
their age group. Girls also obtain their brevet d'enseignement fondamental, their baccalauréat, and university degrees more often than boys. Even more surprisingly: at the secondary level, not only has the progression of girls been dazzling, but that of boys has also given way to regression. The situation is such that since 2007, the Ministry of Education has stopped publishing data on the success rates for the baccalauréat.

We can only welcome the wide access to high levels of education for Algerian women, and hope that this trend will increase. But the deterioration, not only relative but also absolute, of the education of Algeria's men can only cause anxiety. It is urgent that we to try to understand the reasons for this phenomenon, while also trying to measure its possible consequences. This objective obviously goes beyond that of the present article, in which we can only offer a few hypothesis.

On the other hand, we can certainly confirm that female progress in Algeria is partly due to their greater academic success: as they continue to succeed, they have an increasing desire to pursue their education, and are less likely to be discouraged by arguments dissuading them from doing so. There are other factors, however, which must be taken into account, most notably the changing attitudes towards the family. Once we take these factors into account, we should also be able to understand why girls have higher rates of success, and a contrario, why boys fail. Why are they so often unmotivated, and why so early? Do they have other ambitions outside of their education?

The consequences of this phenomenon undoubtedly raise more questions than answers, and these questions are exceedingly difficult to answer. How will the men of tomorrow, less educated than the women of their generation, and these same women, better educated than the previous generation, act out their gender roles relations, especially within their marriages? These men and women come from a society that is still largely dominated by an ancestral principle of male superiority, a principle that still strongly encourages men to marry women who are less educated than themselves. One could certainly hope that this phenomenon will serve to improve existing gender relations, allowing women to have a married and family life without having to sacrifice their professional careers. This phenomenon could also serve to exacerbate tensions concerning gender, however, and it is possible that this gender evolution will be marked by violence. All of these questions could be addressed in an upcoming article, although it is unlikely that they will all be answered.

\section{References}

MANSOURI-ACHERRAR Leïla (1996), La scolarisation des filles en Algérie, Recherches internationales, $\mathrm{n}^{\circ}$ 43-44, Hiverprintemps 1996, pp. 179-190.

BeAudelot Christian et ESTABLET Roger (1992), « Allez les filles ! Paris, Seuil, 243 p.

BOUCHET -VALAT Milan (2015), «Plus diplômées, moins célibataires. L'inversion de l'hypergamie féminine au fil des cohortes en France. Population-F, 70 (4), 2015, pp705-730

CASPARd, (2007), «A quoi tient la supériorité des filles ? Contribution à l'analyse historique d'un problème. Histoire de l'Education (en ligne), 115-116/2007

CENEAP, (2000), «Femmes et hommes en Algérie. Image statistique ». Étude nationale sur le genre. Rapport final. Alger, Centre national d'études et d'analyse pour la population. $187 \mathrm{p}$.

CNES, (2005), Rapport national sur le développement humain. Alger, Conseil national économique et social, $117 \mathrm{p}$.

CNES, (2006), Rapport national sur le développement humain. Alger, Conseil national économique et social, $102 \mathrm{p}$.

CNES, (2011), «Éducation-Formation » Unpublished Statistic Tables given to the author (14 pages.)

CNES, (2016), Rapport national sur le développement humain 2013-2015. Quelle place pour les jeunes dans la perspective du développement humain durable en Algérie ? Alger, Conseil national économique et social, 204 p.

CNRES, (1974), Étude statistique nationale de la population. Résultats de l'enquête démographique. I Structures. Série 2, Volume 4, Oran, Commissariat national aux recensements et enquêtes statistiques, 358 p.

CNRES, (1979), Annuaire statistique de l'Algérie, Résultats 1977-78, Alger, Commissariat national aux recensements et enquêtes statistiques, 379 pages+ Annexes (XIII pages).

CNRP, (1967), Recensement général de la population et de l'habitat 1966 Exploitation par sondage. Volume 1, Oran, Commissariat national aux recensements et enquêtes statistiques, $291 \mathrm{p}$

Constitution of 10 September 1963 on fundamental rights. Order n $76-35$ of 16 April 1976, amended and completed, on the organization of education and training.

DGPEE, (1965): Annuaire statistique de l'Algérie, Nouvelle série. Premier volume. 1963-1964. Alger, Direction générale du plan et des études économiques, 372 p. 
Education News, (2014), «Bac en Algérie, taux de réussite chez les filles, 67,61\% », Alger, 4 juillet 2014. Consulté en novembre 2015.

EsteVe Albert, García-ROMÁn Joan, Permanyer IñakI, 2012: The Gender-Gap Reversal in Education and Its Effect on Union Formation: The End of Hypergamy? Population and development Review 38(3): 535-546 (september 2012)

Esteve, A., Schwartz, C. R., Van Bavel, J., Permanyer, I., Klesment, M. and García-Román, J. (2016), The End of Hypergamy: Global Trends and Implications. Population and Development Review, 42: 615-625. doi:10.1111/padr.12012

INS, (2001): Annuaire statistique de la Tunisie, Année 2001. Tunis, Institut national de la statistique, 293 p. Annuaire $\mathrm{n}^{\circ} 44$

INS, (2011): Annuaire statistique de la Tunisie, Année 2006-2010. Tunis, Institut national de la statistique, $351 \mathrm{p}$. Annuaire $\mathrm{n}^{\circ} 53$.

Kocoglu,Y. (2014):. « Formation et emploi des jeunes dans les pays méditerranéens »; Fiche pays système d'éducation et de formation : Algérie. Marseille, OCEMO, 11p.

LEVY Michel-Louis., (1981), « Garçons et filles à l'école », Population et sociétés, n 151, p. 1-3

MEN (2008), «Loi d'orientation sur l'éducation nationale $n^{\circ}$ 08-04 du 23 janvier 2008 ». Alger, Ministère de l'Education Nationale, $\mathrm{N}^{\circ}$ spécial, 60 pages

MEN, (2015), «Taux de réussite à l'examen du Brevet d'enseignement Moyen session 2015 », Alger, Ministère de l'Education Nationale: www.education.gov.dz/fr/taux-de-reussite-a-lexamen-du-brevet-denseignementmoyen-session-2015/ (web side consulted 4 november 2015)

ONS, (1989), «Recensement général de la population et de l'habitat - 1987-. Données synthétiques » Alger, ONS, 180 p. (Coll. Statistiques, $\mathrm{n}^{\circ}$ 16, série Analyse).

ONS, (1993a), «Recensement général de la population et de l'habitat de 1987. Données synthétiques par Wilaya.» Alger, ONS, 180 p. (Coll. Statistiques, $n^{\circ}$ 54, série Résultats Volume ${ }^{\circ}$ 05).

ONS, (1993b), Données synthétiques par wilaya. Recensement général de la population et de l'habitat Mars 1987. Alger, Office national des statistiques, $153 \mathrm{p}$. Collections statistiques $\mathrm{n}^{\circ} 54$.

ONS, (1994), «Enquête Algérienne sur la Santé de la Mère et de l’Enfant, 1992 ». Rapport principal. » Alger, ONS, $256 \mathrm{p}$.

ONS, (1994), «Enquête Algérienne sur la Santé de la Mère et de l’Enfant, 1992 ». Rapport principal. » Alger, ONS, $256 \mathrm{p}$.

ONS, (1998), « Démographie algérienne 1997 », Alger, Office national des statistiques, 8 p. (Données statistiques, $\left.\mathrm{n}^{\circ} 277\right)$

ONS, (1999), "Recensement général de la population et de l'habitat 1998. Les principaux résultats du sondage au $1 / 10^{\text {ème }}$. ». Alger, ONS, 180 p. (Coll. Statistiques, $n^{\circ}$ 80, série Résultats $n^{\circ} 01$ ).

ONS, (2001), «Annuaire statistique de l'Algérie, résultats 1997/1999. » Alger, Office national des statistiques, 372 p. (Annuaire $\mathrm{n}^{\circ} 19$ ).

ONS, (2004), « Enquête Algérienne sur la Santé de la famille, 2002 ». Rapport principal. » Alger, ONS, 374 p.

ONS, (2006), « L’Algérie en quelques chiffres. Résultats 2005 ». n³6, 57 p.

ONS, (2009a), «L'Algérie en quelques chiffres. Résultats 2008 ». n³ 39, 62 p.

ONS, (2009b), «RGPH 2008. Les principaux résultats du sondage au $1 / 10^{\text {ème }}$ ». Alger, Office national des statistiques, 189 p. Collections statistiques, Série $S$, statistiques sociales, $n^{\circ} 142$.

ONS, (2010a), « L'Algérie en quelques chiffres. Résultats 2007-2009». n 40, 63 p.

ONS, (2010b), «Education et scolarisation en Algérie à travers les résultats du RGPH 2008». Résultats par wilaya. Alger, Office national des statistiques 173 p. (Collections statistiques, Série $\mathrm{S}$, statistiques sociales, $\mathrm{n}^{\circ} 157$ ).

ONS, (2011), "Education et scolarisation en Algérie à travers les résultats du RGPH 2008». Résultats par wilaya. Alger, Office national des statistiques173 p. (Collections statistiques, Série S, statistiques sociales, $\mathrm{n}^{\circ} 157$ ).

ONS, (2012a), «Rétrospective 1960-2011». Chapitre 6 : Education. Publication disponible sur le site de l'ONS, PDF. Office national des statistiques, Alger, $249 \mathrm{p}$.

ONS, (2012b), «L'Algérie en quelques chiffres». Publication disponible sur le site de l'ONS, PDF. Office national des statistiques, Alger, 49p.

ONS, (2013), Annuaire statistique de l'Algérie, résultats 2009-2011. Alger, Office national des statistiques, 372 p. Annuaire $\mathrm{n}^{\circ} 29$.

ONS, (2013b), Annuaire statistique de l'Algérie, résultats 2009-2011. Alger, Office national des statistiques, 372 p. Annuaire $\mathrm{n}^{\circ} 29$.

OuADAH-BEDIDI Zahia (2004), «Baisse de la fécondité en Algérie : Transition de développement ou transition de crise ?» Sous la dir. de Thérèse Locoh. - Paris, 2004. - 2 vol. (XXXIII-710) p. 
PNUD, 1991, Rapport mondial sur le développement humain 1991, Paris Economica, 138 p.

UNESCO, (2015), Web site (http://www.uis.unesco.org), consultation of $27^{\text {th }}$ october 2015»

UNESCO, 1989, Annuaire de l'UNESCO 1989.

UNICEF, (2014), «Algérie, rapport national sur les enfants non scolarisés ». Alger, Unicef, 103 p.

\section{Appendix 1}

Administrative organization of Algeria, the 48 wilayas according to the $1987^{\mathrm{xi}}$ and 2008 censuses

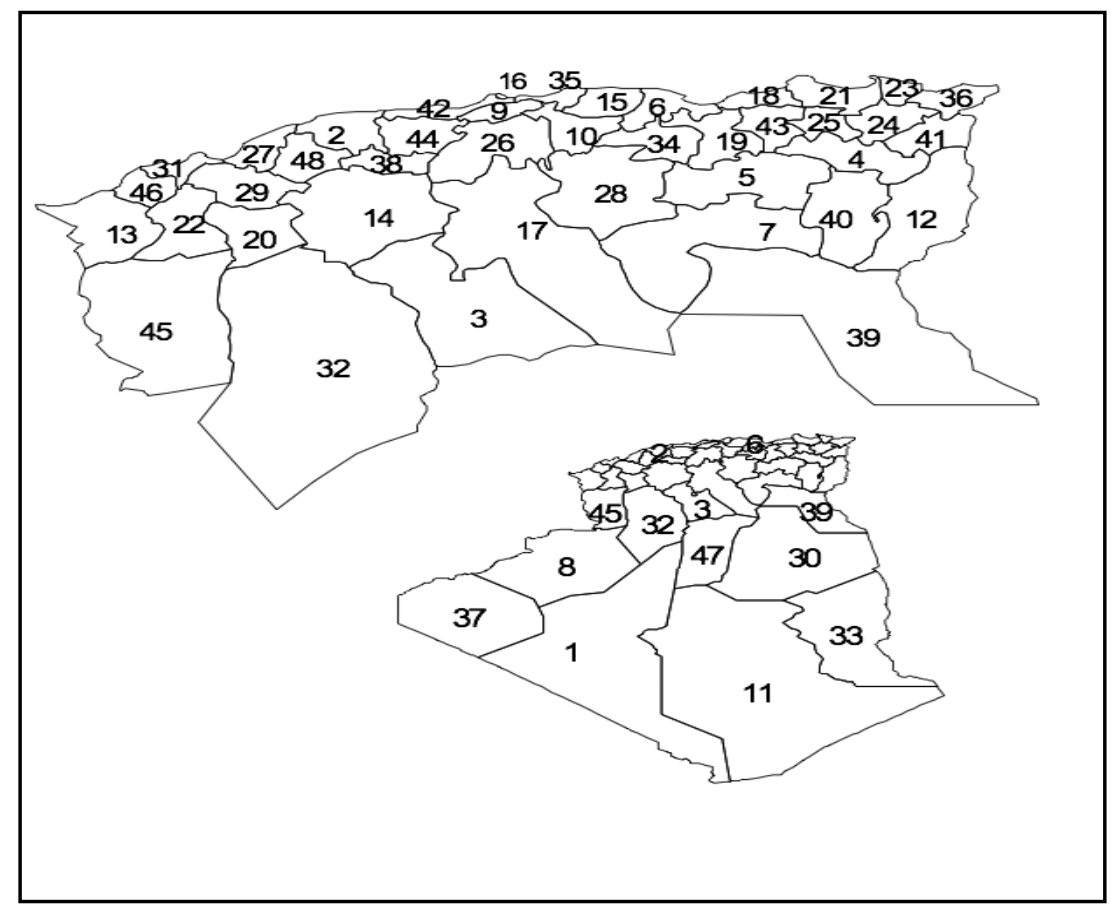


Appendix 2: Percentage of men and women who have attained the secondary and higher level of education according to age group, sex and wilaya according to the 1987 and 2008 censuses

\begin{tabular}{|c|c|c|c|c|c|c|c|c|c|c|}
\hline \multirow[b]{3}{*}{ Code } & \multirow[b]{3}{*}{ Wilaya } & \multicolumn{6}{|c|}{2008} & \multirow{2}{*}{\multicolumn{3}{|c|}{$\frac{1987}{\text { Secondary à } 15-19}$}} \\
\hline & & \multicolumn{3}{|c|}{ Secondary à 15-19 } & \multicolumn{3}{|c|}{ University a 20-24 } & & & \\
\hline & & Maes & Females & Difference & Maes & Females & Difference & Maes & Females & Difference \\
\hline 1 & Adrar & 29,1 & 29,2 & $-0,1$ & 18,5 & 15,4 & 3,1 & 29,9 & 6,0 & 23,9 \\
\hline 2 & Chlef & 23,1 & 27,8 & $-4,7$ & 13 & 21,1 & $-8,1$ & 26,9 & 17,0 & 9,9 \\
\hline 3 & Laghouat & 33,9 & 35,8 & $-1,9$ & 19,3 & 23,4 & $-4,1$ & 32,2 & 19,5 & 12,7 \\
\hline 4 & Oum El Bouaghi & 23,9 & 31,5 & $-7,6$ & 13,4 & 23,5 & $-10,1$ & 28,4 & 22,0 & 6,4 \\
\hline 5 & Batna & 24,3 & 31,7 & $-7,4$ & 16,4 & 27,2 & $-10,8$ & 30,0 & 20,6 & 9,4 \\
\hline 6 & Bejaia & 23,3 & 32,5 & $-9,2$ & 18,1 & 27,3 & $-9,2$ & 33,0 & 15,4 & 17,6 \\
\hline 7 & Biskra & 21,8 & 29,2 & $-7,4$ & 15 & 24,5 & $-9,5$ & 31,7 & 20,4 & 11,3 \\
\hline 8 & Bechar & 26,9 & 35,3 & $-8,4$ & 15 & 22,8 & $-7,8$ & 34,3 & 24,4 & 9,9 \\
\hline 9 & Blida & 21,2 & 32,2 & -11 & 14,8 & 26,2 & $-11,4$ & 31,5 & 26,2 & 5,3 \\
\hline 10 & Bouira & 25,1 & 34,1 & -9 & 15,9 & 24,5 & $-8,6$ & 26,9 & 18,0 & 8,9 \\
\hline 11 & Tamanrasset & 19,8 & 20,6 & $-0,8$ & 11,7 & 12,6 & $-0,9$ & 38,4 & 11,7 & 26,7 \\
\hline 12 & Tébessa & 27,5 & 29,3 & $-1,8$ & 14 & 19,7 & $-5,7$ & 29,3 & 15,4 & 14,0 \\
\hline 13 & Tlemcen & 27,2 & 32,8 & $-5,6$ & 18 & 23,6 & $-5,6$ & 26,7 & 21,2 & 5,5 \\
\hline 14 & Tiaret & 23,5 & 29,4 & $-5,9$ & 11,8 & 20,2 & $-8,4$ & 25,9 & 19,2 & 6,7 \\
\hline 15 & Tizi Ouzou & 22,9 & 36,8 & $-13,9$ & 15,9 & 32,1 & $-16,2$ & 27,5 & 20,9 & 6,6 \\
\hline 16 & Alger & 25,5 & 37,3 & $-11,8$ & 18,1 & 34 & $-15,9$ & 37,4 & 43,9 & $-6,6$ \\
\hline 17 & Djelfa & 27,3 & 27,3 & 0 & 14,9 & 13,8 & 1,1 & 28,9 & 10,2 & 18,8 \\
\hline 18 & Jijel & 20,8 & 32,4 & $-11,6$ & 15,8 & 28,7 & $-12,9$ & 25,1 & 16,2 & 8,8 \\
\hline 19 & Sétif & 20,2 & 29 & $-8,8$ & 13 & 22,6 & $-9,6$ & 23,6 & 16,8 & 6,8 \\
\hline 20 & Saida & 24,2 & 30 & $-5,8$ & 14,5 & 21,4 & $-6,9$ & 30,5 & 21,3 & 9,2 \\
\hline 21 & Skikda & 19,6 & 28,7 & $-9,1$ & 16,1 & 29,8 & $-13,7$ & 29,4 & 24,6 & 4,7 \\
\hline 22 & Sidi Bel Abbes & 27,9 & 33,9 & -6 & 15,4 & 24,5 & $-9,1$ & 27,5 & 22,4 & 5,1 \\
\hline 23 & Annaba & 29,9 & 40 & $-10,1$ & 20,8 & 35,7 & $-14,9$ & 29,9 & 36,0 & $-6,1$ \\
\hline 24 & Guelma & 25,8 & 36,4 & $-10,6$ & 14,4 & 30,4 & -16 & 26,9 & 24,1 & 2,8 \\
\hline 25 & Constantine & 23,8 & 36,3 & $-12,5$ & 18,2 & 35,9 & $-17,7$ & 27,9 & 29,6 & $-1,6$ \\
\hline 26 & Médéa & 22,9 & 28,8 & $-5,9$ & 13,8 & 20,4 & $-6,6$ & 22,7 & 10,6 & 12,2 \\
\hline 27 & Mostaganem & 22,6 & 23,4 & $-0,8$ & 13,2 & 17,1 & $-3,9$ & 25,0 & 12,9 & 12,0 \\
\hline 28 & M'sila & 22,3 & 28,6 & $-6,3$ & 13,1 & 18 & $-4,9$ & 29,3 & 11,6 & 17,7 \\
\hline 29 & Mascara & 22,1 & 24,6 & $-2,5$ & 14,1 & 19,1 & -5 & 23,8 & 16,1 & 7,7 \\
\hline 30 & Ouargla & 23,8 & 30,6 & $-6,8$ & 17,1 & 22,8 & $-5,7$ & 39,0 & 19,6 & 19,3 \\
\hline 31 & Oran & 22,7 & 30,9 & $-8,2$ & 16,2 & 25,6 & $-9,4$ & 29,2 & 29,8 & $-0,5$ \\
\hline 32 & El Bayadh & 24,4 & 30 & $-5,6$ & 16,3 & 23,1 & $-6,8$ & 32,7 & 20,9 & 11,8 \\
\hline 33 & Illizi & 15,1 & 20 & $-4,9$ & 8 & 10,1 & $-2,1$ & 33,8 & 9,2 & 24,6 \\
\hline 34 & Bordj B. Arreridj & 27,5 & 34,3 & $-6,8$ & 15,1 & 23,1 & -8 & 23,5 & 16,2 & 7,3 \\
\hline 35 & Boumerdes & 17,8 & 30,7 & $-12,9$ & 11,2 & 25,4 & $-14,2$ & 26,2 & 24,5 & 1,7 \\
\hline 36 & El Tarf & 26,1 & 36,1 & -10 & 12,2 & 26,6 & $-14,4$ & 29,2 & 27,1 & 2,1 \\
\hline 37 & Tindouf & 20,1 & 26 & $-5,9$ & 11,5 & 14,7 & $-3,2$ & 35,7 & 27,5 & 8,2 \\
\hline 38 & Tissemsilt & 25,5 & 29 & $-3,5$ & 14,1 & 22,2 & $-8,1$ & 23,1 & 10,7 & 12,4 \\
\hline 39 & El Oued & 25,3 & 31,2 & $-5,9$ & 15,9 & 17,9 & -2 & 30,6 & 11,8 & 18,8 \\
\hline 40 & Khenchela & 29,2 & 34,2 & -5 & 16,2 & 25,1 & $-8,9$ & 29,2 & 17,3 & 11,9 \\
\hline 41 & Souk Ahras & 25,3 & 31 & $-5,7$ & 13,1 & 25,8 & $-12,7$ & 23,8 & 19,2 & 4,5 \\
\hline 42 & Tipaza & 19,5 & 28,8 & $-9,3$ & 13,3 & 25 & $-11,7$ & 26,9 & 26,3 & 0,6 \\
\hline 43 & Mila & 21,7 & 31,4 & $-9,7$ & 14,6 & 25,9 & $-11,3$ & 25,5 & 18,2 & 7,3 \\
\hline 44 & Ain Defla & 21,7 & 26,3 & $-4,6$ & 12,8 & 20,9 & $-8,1$ & 28,5 & 16,0 & 12,4 \\
\hline 45 & Naama & 25,8 & 30,6 & $-4,8$ & 15 & 18,7 & $-3,7$ & 35,6 & 22,4 & 13,2 \\
\hline 46 & Ain Temouchent & 25,4 & 33,4 & -8 & 14,1 & 24,4 & $-10,3$ & 26,5 & 26,4 & 0,2 \\
\hline 47 & Ghardaïa & 28,2 & 35,2 & -7 & 18,7 & 16,9 & 1,8 & 41,1 & 16,7 & 24,4 \\
\hline 48 & Relizane & 24,9 & 26,5 & $-1,6$ & 15,3 & 18,9 & $-3,6$ & 21,1 & 12,5 & 8,5 \\
\hline & Algeria & 23,9 & 31,3 & $-7,4$ & 15,2 & 24,4 & $-9,2$ & 28,7 & 22,1 & 6,6 \\
\hline & $\max$ & 33,9 & 40 & 0 & 20,8 & 35,9 & 3,1 & 41,1 & 43,9 & 26,7 \\
\hline & $\min$ & 15,1 & 20 & $-13,9$ & 8,0 & 10,1 & $-17,7$ & 21,1 & 6,0 & $-6,6$ \\
\hline
\end{tabular}




\footnotetext{
i The constitution of 1963 stipulates in article 18 that "schooling is compulsory", while article 10 guarantees free education, and article 12 guarantees equal rights and obligations regardless of sex. The constitution does not precise, however, the age range to which these articles apply, and is even more vague regarding the level of education that students are expected to attain. Only the order of 16 April 1976 specifies that schooling is compulsory from the ages of 6 to 16 (articles 4 to 7), the age range that has been enforced in France since order no. 59-45 of 6 January 1959.

ii In Algeria, what is referred to as "basic" or "fundamental" education corresponds to the schooling administered in France during primary school (the $1^{\text {st }}$ and $2^{\text {nd }}$ cycles of basic education in Algeria) and middle school (the $3^{\text {rd }}$ cycle of basic education, also called "middle").

iii The result given in Table 1 for 1969 only concerns northern Algeria, and is not necessarily comparable to the results from previous years that take the entire country into account.

${ }^{\text {iv }}$ The Tables currently in publication have been generously provided to the author.

${ }^{v}$ According to this source, the total number of candidates was 657,026, including 369,675 girls. If every student had showed up to exams, the boys' success rate would have been $15.9 \%$. More precisely, if we apply the same proportion of candidates who actually showed up to exams in 2015 (95\% for girls and 90\% for boys), the boys' success rate would have only been 14 $\%$.

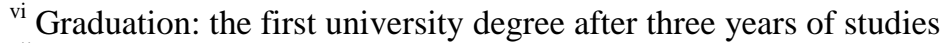

vii To the question: “What is the main reason why (NAME) dropped out of school?",question \#111 of the household questionnaire of the 2002 PAPFAM survey (MSRH, ONS, LEA, 2004).

viii "If you answered that you no longer attend school, but that you have attended school in the past: what is the main reason why you dropped out of school?" question \#117 of the «Young people » section of the survey, with 7 types of responses(MSRH, ONS, LEA, 2004)

ix The maximum age limit for compulsory schooling until 1976, when it was raised to 16 .

${ }^{x}$ Out of 122,390 respondents in the 2002 survey, $2.6 \%$, or 3126 respondents, were aged 14 .

${ }^{x i}$ It should be noted, however, that from 1987 to 2008, the wilaya of Algiers grew with the addition of several communes which had previously been counted as part of adjacent wilayas (Tipaza, Blida and Boumerdes).
} 